\title{
O DIREITO À NÃO AUTO-INCRIMINAÇÃO E AS PESSOAS COLECTIVAS EMPRESARIAIS
}

\author{
JÓNATAS E. M. MACHADO* \\ VERA L. C. RAPOSO**
}

\begin{abstract}
RESUMO: O artigo tem a finalidade de oferecer notas sobre a doutrina e jurisprudência com relação ao direito à não auto-incriminação. $\mathrm{O}$ foco é a aplicação desse direito em relações envolvendo pessoas coletivas, especialmente aquelas dedicadas à atividade econômica regulada.

PALAVRAS-CHAVE: Não auto-incriminação. Pessoas coletivas. Atividade econômica regulada.
\end{abstract}

\begin{abstract}
The article aims at offering a few notes on the doctrine and jurisprudence relating to the right against self-incrimination. The focus is the application of this right in relationships involving legal persons, especially those dedicated to regulated economic activity.

KEYWORDS: Right against self-incrimination. Legal persons. Regulated economic activity.

SUMÁRIO: 1. Introdução; 2. Fundamentos do direito à não auto-incriminação; 3. O desenvolvimento jurisprudencial do direito à não auto-incriminação; 4. Garantias processuais das pessoas colectivas; 5 . Conclusão.

SUMMARY: 1. Introduction; 2. Foundations of the right against self-incrimination; 3 . The jurisprudential development of the right against self-incrimination; 4. Procedural guarantees of legal persons; 5. Conclusion.
\end{abstract}

\section{INTRODUÇÃO}

O presente estudo tem o modesto objectivo de fornecer aos operadores jurídicos algumas notas doutrinais e jurisprudenciais sobre o direito à não auto-incriminação. Baseado na conhecida máxima latina "Nemo tenetur se ipsum accusare" (ninguém pode ser obrigado a acusar-se a si próprio), este direito, com uma longa carreira na história do direito, tem conhecido desenvolvimentos importantes em vários contextos jurídicos.

A nossa atenção irá incidir, preponderantemente, na relevância que este importante instrumento de salvaguarda dos direitos fundamentais pode adquirir quando estejam em causa pessoas colectivas. Pensamos principalmente nas sociedades comerciais que se dedicam a actividades económicas, com especial relevo para as actividades

Artigo recebido em 20.08.2009 e aprovado para publicação pelo Conselho Editorial em 14.10.2009.

* Professor Associado da Faculdade de Direito da Universidade de Coimbra

** Assistente da Faculdade de Direito da Universidade de Coimbra. 
reguladas, as quais exigem um contacto directo com entidades administrativas de regulação e supervisão. As controvérsias e os problemas práticos que se colocam a propósito deste direito são múltiplos, não havendo possibilidade de dar conta deles dentro dos limites impostos por um artigo doutrinal. Limitar-nos-emos, por isso, a dar conta de alguns dos aspectos essenciais desta problemática, ainda que estejamos plenamente conscientes de que este direito, pela sua complexidade histórica e doutrinal, não se compadece com leituras simplistas.

\section{FUNDAMENTOS DO DIREITO À NÃO AUTO-INCRIMINAÇÃO}

\subsection{Fundamento constitucional}

O direito à não auto-incriminação consiste no direito a não ser forçado a depor como testemunha contra si mesmo em processo penal ${ }^{1}$. O mesmo encontra-se materialmente vinculado ao princípio da presunção da inocência e ao direito a um julgamento justo. Nos alvores do constitucionalismo moderno, ele encontrou uma firme radicação na Quinta Emenda à Constituição Federal norte-americana, de $1787^{2}$. Mesmo quando não expressamente consagrada nos textos constitucionais, o direito à não auto-incriminação deduz-se das garantias de processo equitativo. O seu conteúdo reflecte um vasto conjunto de preocupações, todas elas relacionadas com o objectivo de evitar que uma pessoa inocente seja indevida e injustamente condenada.

Subjacente ao direito à não auto-incriminação encontra-se igualmente um princípio de prevenção do abuso de poder na recolha de informações, da invasão da privacidade e da recolha de elementos probatórios destituídos de fidedignidade. Igualmente relevante é o princípio da voluntariedade da confissão, de acordo com o qual a confissão deve resultar de uma escolha livre e não constrangida por parte do arguido. Pelo seu conteúdo, o direito à não auto-incriminação deve ser interpretado em termos razoavelmente amplos, a favor do arguido, na medida em que isso seja suportado por uma correcta ponderação dos princípios relevantes ${ }^{3}$.

Na origem histórica deste direito está a necessidade de proteger os arguidos diante dos interrogatórios policiais, como meio de evitar confissões coagidas. Este direito surgiu como uma reacção consciente contra as práticas inquisitoriais medievais, na linha do instituto da Prohibitio Formata através do qual se pretendeu restringir os direitos de interrogação do clero ${ }^{4}$. Presentemente, o mesmo tem como ponto de partida o reconhecimento da fragilidade do indivíduo perante o monopólio estadual da coerção legítima. O direito à não auto-incriminação sofre, naturalmente, as restrições necessárias e adequadas à realização da finalidade constitucional da boa

\footnotetext{
${ }^{1}$ Se prejuízo da sua relevância em processos não penais. Veja-se, G. Ray Kolb, Jr. AND William L. Pfeifer, Jr, “Assertion of the Fifth Amendment Privilege Against Self-Incrimination in Civil Proceedings”, 67, The Alabama Lawyer, 2006, 40 ss.; John Fabian Witt, "Making the Fifth: The Constitutionalization of American Self-Incrimination Doctrine, 1791-1903”, 77 Texas Law Review, 1999, 825 ss.

${ }^{2}$ Mary Shein, “The Privilege Against Self-Incrimination Under Siege: Asherman v. Meachum”, 59, Brooklyn Law Review, 1993, 503.

${ }^{3}$ Vincent Martin Bonventre, “An Alternative to the Constitutional Privilege Against Self-Incrimination”, 49, Brooklyn Law Review, 1982, 31 ss.

${ }^{4}$ Sobre este ponto, Bonventre, An Alternative to An Alternative to the Constitutional Privilege Against Self-Incrimination..., cit., 35 ss.
} 
administração da justiça e do combate à criminalidade. Tende a considerar-se que, dentro de certos limites, pode haver lugar à auto-incriminação, desde que não se recorra a métodos cruéis e proibidos de obtenção de prova e se garanta a fidedignidade dos depoimentos prestados. Ainda assim, na medida em que se trata de um direito fundamental, o mesmo deve ser construído com um âmbito de protecção alargado. Do mesmo modo, havendo dúvidas sobre o respectivo conteúdo, deve optar-se pela interpretação mais favorável ao respectivo titular.

\subsection{Fundamento jurídico-internacional}

$\mathrm{O}$ direito à não auto-incriminação tem hoje um fundamento jurídico-internacional. $\mathrm{O}$ mesmo deduz-se dos direitos processuais de defesa consagrados na generalidade dos instrumentos de direito internacional de direitos humanos, tanto de alcance universal, como regional. Este direito encontra-se consagrado no artigo $14^{\circ}$ do Pacto Internacional sobre Direitos Civis e Políticos. No âmbito do artigo $6^{\circ}$ da Convenção Europeia dos Direitos do Homem, o direito ao silêncio e à não auto-incriminação tem vindo a ser objecto de concretização pela Comissão Europeia dos Direitos do Homem e pelo Tribunal Europeu dos Direitos do Homem (TEDH).

$\mathrm{O}$ direito à não auto-incriminação é hoje considerado um direito humano fundamental, assente no princípio básico de que ninguém pode ser obrigado a testemunhar contra si próprio ${ }^{5}$. A partir do direito internacional dos direitos humanos, este direito tem irradiado até às diferentes constituições dos vários Estados. O mesmo integra hoje as dimensões essenciais do due process of $l a w^{6}$, sendo uma realidade incontornável em todos os processos sancionatórios, especialmente nos casos em que estes abram as portas a ulteriores processos penais ${ }^{7}$. Acresce que o direito à não autoincriminação tem hoje um fundamento jurídico-internacional. No âmbito do artigo $6^{\circ}$ da Convenção Europeia dos Direitos do Homem, o direito ao silêncio e à não autoincriminação tem vindo a ser objecto de concretização pela Comissão Europeia dos Direitos do Homem e pelo Tribunal Europeu dos Direitos do Homem (TEDH).

\subsection{Fundamento material}

Independentemente da sua consagração no direito constitucional e internacional, o direito à não auto-incriminação carece de uma justificação material que ajude a esclarecer os seus limites. É que este direito deve ser sempre compatibilizado com a finalidade constitucional substantiva, indeclinável num Estado de direito, de prossecução penal das mais graves infracções. Esta finalidade é essencial para a tutela dos direitos fundamentais dos particulares e de outros bens jurídicos da comunidade e do Estado.

Este direito tem um fundamento material de dupla natureza, substantiva e processual. Do ponto de vista substantivo, como anteriormente se disse, este direito encontra-se radicado na presunção da inocência e no direito a um julgamento justo e

\footnotetext{
${ }^{5}$ Marc Berger, "Europeanizing Self-Incrimination: The Right to Remain Silent in the European Court of Human Rights”, Columbia Journal of European Law, 12, 2006, p. 339 ss.

${ }^{6}$ Vera Lúcia Raposo, "O Direito a um Processo Equitativo na Jurisprudência do Tribunal Europeu dos Direitos do Homem”, Jurisprudência Constitucional, n. ${ }^{\circ}$ 11, Julho-Setembro 2006, p. 3 ss.

${ }^{7}$ Constantine Theophilopoulos, "The Anglo-American Privilege Against Self-Incrimination and the Fear of Foreign Prosecution”, Sydney Law Review, 14, 2003.
} 
serve o objectivo de evitar abusos de poder por parte do Estado que possam levar à condenação injusta de arguidos inocentes. Do mesmo modo, ele pretende proteger a dignidade, a privacidade e a autonomia individual durante o processo ${ }^{8}$. Além disso, do ponto de vista processual, o direito à não auto-incriminação é indissociável da estrutura acusatória do processo, nos termos da qual é a quem acusa que cabe provar a culpa do arguido, sem dele pretender extrair confissões.

A esta luz, como já se disse, o direito à não auto-incriminação integra uma opção consciente de rejeição da estrutura inquisitorial do processo, estrutura essa que dava ampla margem à interrogação do arguido e à tentação do uso de meios de pressão e de tortura, física e psicológica, em ordem a obter ou forçar a confissão. O mesmo decorre, igualmente, dos princípios processuais do contraditório e da igualdade de armas, à luz dos quais seria inaceitável que uma das partes pudesse compelir a outra a apresentar provas em seu próprio prejuízo ${ }^{9}$. Alguma doutrina estabelece uma ligação entre o direito à não auto-incriminação, enquanto manifestação do direito a permanecer em silêncio, e o dever de dizer a verdade durante o processo.

A garantia do direito à não auto-incriminação tem subjacente a ideia de que o processo penal nem sempre conduz a resultados certos e inequívocos, em que os culpados são condenados e os inocentes absolvidos. Antes o mesmo pode assumir um grau considerável de indeterminação, podendo a investigação ser conduzida de forma incorrecta e perturbada por um número de variáveis de difícil controlo e de circunstâncias ambíguas. As águas do processo penal nem sempre são límpidas e transparentes, podendo ser, nalguns casos, turvas e perigosas. Assim, se é verdade que o direito à não auto-incriminação pode servir de defesa ao culpado, também o é que em muitos casos ele é essencial à protecção dos inocentes ${ }^{10}$.

O conteúdo essencial do direito à não auto-incriminação é relativamente pacífico, quando aplicável a indivíduos em processo penal. Mas ele vai mais além, reconhecendo-se também o direito a não responder a perguntas potencialmente incriminatórias, mesmo que não exista ainda qualquer processo penal formalmente instaurado. Decisiva, neste contexto, é a existência de um risco plausível de posterior incriminação.

No entanto, os limites exteriores deste direito tornam-se mais problemáticos quando se pondera a sua aplicação a pessoas colectivas, mesmo em processo penal, ou a indivíduos e pessoas colectivas em processos sancionatórios de natureza não penal. Daí que seja importante ter uma ideia clara acerca da sua ratio essendi. Esta, na medida em que se apresenta indissoluvelmente ligada à garantia de um julgamento justo, aplica-se também às pessoas colectivas que sejam objecto de procedimentos sancionatórios.

\section{4. Âmbito de protecção do direito à não auto-incriminação}

Uma vez referenciado o fundamento jurídico, constitucional e internacional, do direito à não auto-incriminação e explicitado o respectivo fundamento material, importa tecer algumas considerações a respeito do seu âmbito de protecção. Sobre esta questão a doutrina não tem uma posição uniforme. No entanto, deve salientar-se

${ }^{8}$ Theophilopoulos, The Anglo-American Privilege Against Self-Incrimination....., cit., idem.

${ }^{9}$ Veja-se, Antônio Magalhães Gomes Filho, Direito à Prova no Processo Penal, RT, item 7, 1997, p.111.

${ }^{10}$ Neste sentido, Lochower v. Board of Higher Education of New York City, 350 U.S. 551 (1956). 
aquela perspectiva que vê o direito à não auto-incriminação como uma subcategoria dentro do direito ao silêncio em sentido amplo, que compreende o direito a não ser obrigado a fazer afirmações auto-incriminatórias através do recurso à violência física ou moral ou meios fraudulentos e moralmente ilegítimos. Embora os contornos precisos deste direito ainda sejam debatidos na doutrina e na jurisprudência, como veremos adiante, existem já algumas dimensões que podem ser consideradas sedimentadas ${ }^{11}$.

Assim, é hoje líquido que o mesmo pode ser invocado diante de um tribunal comum num processo penal, bem como num processo civil ou administrativo, sempre que exista um risco razoável de um processo penal subsequente. Isto, note-se, sem prejuízo da possibilidade de invocação durante as fases preliminares de investigação ou inquérito. Acresce que a invocação do direito pode ser feita pelo próprio titular ou pelo seu representante legal e é independente do estatuto processual da pessoa, podendo a ele recorrer quem seja testemunha, suspeito, indiciado ou arguido num processo sancionatório. Do mesmo modo, dada a sua radicação no direito internacional dos direitos humanos, a invocação do direito em presença é independente da qualidade de nacional ou estrangeiro ou de residente legal ou ilegal.

O direito à não auto-incriminação propriamente dito, inclui o direito a não ser obrigado a fornecer qualquer elemento de prova que possa contribuir para a auto-incriminação $^{12}$. Trata-se de um direito que deve ser invocado questão a questão e não de um modo geral e abstracto. O direito deve ser invocado perante uma pergunta ou um pedido específico, não podendo valer-se do direito à não auto-incriminação quem já tenha sido condenado pela infracção ou quem já não o possa ser em virtude das regras da prescrição.

O direito também não protege o direito de prestar informações falsas ou de negar a prática de infracções. Ele não pretende constituir um obstáculo intransponível à realização da justiça, sancionando a condenação de um inocente ou a absolvição de um culpado. A sua razão de ser consiste, apenas, em garantir a não condenação de um inocente, devendo a mesma alertar contra os riscos de uma sobre-interpretação do direito ${ }^{13}$. No entanto, sendo a culpa ou a inocência aferida apenas em processo penal, o direito deve ser entendido à luz de uma correcta, equilibrada e fundamentada aplicação das garantias de defesa do arguido. Uma questão que fica em aberto prende-se com saber se e em que medida podem ser mobilizados os princípios da boa fé e da proibição do abuso do direito quando da sua invocação, nomeadamente em casos de invocação selectiva.

${ }^{11}$ Theophilopoulos, The Anglo-American Privilege Against Self-Incrimination......, cit., idem.

${ }^{12}$ Pedro Luis de Amaral Marino, “O Dever de Informar e o Direito ao Silêncio”, Direito penal tributário contemporâneo: estudos de especialistas, Cord. Antônio Cláudio Mariz de Oliveira, Dejalma de Campos, São Paulo, 1995; Heloisa Estellita Salomão, “O Direito Humano de Não Cooperar na Própria Incriminação, a Protecção ao Domicílio e a Fiscalização Tributária”, Revista Brasileira de Ciências Criminais, 7, 26, 1999, p. 131.

${ }^{13}$ Bonventre, An Alternative to An Alternative to the Constitutional Privilege Against Self-Incrimination..., cit., 44 ss. autor que considera que o direito à não-autoincriminação é um instituto que não cumpre as funções que se propõe e que acaba, em muitos casos, por constituir uma obstrução à justiça. Para o autor, este direito supõe uma concepção duelística do processo, que vê o processo penal como luta entre iguais, privando o Estado dos seus poderes de soberania na procura da verdade material. 
Para além deste domínio central de aplicação, existem algumas dimensões deste direito cuja concretização e sedimentação ainda não se encontra totalmente estabilizada e consolidada. A jurisprudência nacional de vários países, a par da jurisprudência internacional e comunitária, tem procurado explicitar e cristalizar as diferentes dimensões deste direito. O resultado alcançado, até ao momento, não é inteiramente satisfatório. Uma das questões controvertidas prende-se, precisamente, em saber se e em que medida as pessoas colectivas se podem valer deste direito em processos sancionatórios que contra elas venham a ser instaurados. $\mathrm{O}$ mesmo se passa relativamente às pessoas físicas que representam essas pessoas colectivas, quando a prestação de informações às autoridades as possa comprometer em ulteriores processos penais.

No entanto, da jurisprudência europeia de direitos humanos e comunitária podem extrair-se já importantes indicações, inteiramente relevantes para o direito interno. Refira-se, do mesmo modo, que a radicação do direito à não auto-incriminação no domínio dos direitos fundamentais constitucionais e dos direitos humanos, de matriz jus-internacional, favorece claramente a sua extensão às pessoas colectivas. Por maioria de razão, o mesmo abrange as pessoas físicas que representem a pessoa colectiva e que corram o risco de vir a ser incriminadas com base em informações prestadas em representação da pessoa colectiva. Este ponto é directamente pertinente para a abordagem do direito à não auto-incriminação a partir dos princípios constitucionais portugueses em matéria de direito sancionatório. Isto, apesar de, como veremos nas linhas subsequentes, a resposta a este problema não ser inteiramente consensual nos diferentes ordenamentos jurídicos.

\section{O DESENVOLVIMENTO JURISPRUDENCIAL DO DIREITO À NÃO AUTO-INCRIMINAÇÃO}

Como vimos, os fundamentos do direito à não auto-incriminação encontram-se bem estabelecidos. O mesmo sucede com os aspectos essenciais do seu conteúdo. No entanto, a doutrina e a jurisprudência ainda divergem nalguns aspectos da determinação do seu âmbito normativo. Uma outra questão não inteiramente estabilizada prende-se com saber se e em que medida é que o direito à não auto-incriminação se aplica também às pessoas colectivas. Trata-se de uma questão controvertida, que não tem conhecido uma solução única nos vários ordenamentos jurídicos.

Nalguns quadrantes, o direito à não auto-incriminação é reconhecido sem quaisquer problemas, aceitando-se como algo natural a extensão dos direitos fundamentais em geral e das garantias processuais em especial às pessoas colectivas. Noutros contextos, rejeita-se a aplicação do direito à não auto-incriminação às pessoas colectivas. Ao mesmo tempo, procura-se indagar dos termos exactos da sua aplicabilidade aos representantes individuais das pessoas colectivas. Nas linhas que se seguem procuraremos dar conta das diferentes perspectivas que se digladiam sobre este tema na jurisprudência nacional comparada, internacional e comunitária.

\subsection{A jurisprudência dos Estados Unidos}

\subsubsection{Entendimento tradicional}

Nos Estados Unidos, o direito à não auto-incriminação aplica-se a testemunhas e a arguidos em processo penal. Já a sua aplicação às empresas tende a ser negada, 
embora a questão seja controvertida na doutrina. No tocante às testemunhas, salientaremos apenas que o direito se aplica a todas as fases do processo penal, incluindo as fases preliminares de investigação, bem como a inquéritos parlamentares e audições administrativas.

A testemunha pode recusar-se a prestar informações ou a fornecer prova documental sempre que daí resulte, para si mesma, um efeito incriminatório, mesmo que a resposta seja apenas um elo na cadeia de provas circunstanciais necessárias à incriminação ${ }^{14}$. O potencial incriminatório das respostas pretendidas deve ser aferido no caso concreto pelo juiz, a partir dos elementos contextuais pertinentes ${ }^{15}$.

A exigência, a uma testemunha, do fornecimento de documentos auto-incriminatórios pode encontrar-se abrangida pelo direito à não auto-incriminação, na medida em que a mesma equivalha, materialmente, à exigência de prestação de testemunho ${ }^{16}$. No entanto, isso não se aplica a documentos em domínios sujeitos a regulação de interesse público, como sejam registos de preços elaborados ao abrigo de regulação de preços $^{17}$. Refira-se que uma testemunha a quem tenham sido apreendidos documentos incriminatórios mediante um mandato de busca válido, não pode invocar o direito à não auto-incriminação, na medida em que este pretende, acima de tudo, prevenir a obtenção de prova testemunhal mediante coerção.

Relativamente aos indivíduos arguidos em processo penal, o direito à não auto-incriminação encontra-se bem consolidado, desde que o mesmo foi consagrado, em 1791, na Quinta Emenda à Constituição Federal de 1787. A fixação do alcance deste direito foi o resultado de um processo gradual de concretização pelo Supremo Tribunal norte-americano. No caso Shapiro $v$ United States ${ }^{18}$, o Supremo Tribunal sustentou que a Quinta Emenda não abrange documentos cuja produção e conservação seja exigida pelo Estado para a realização de finalidades administrativas (required records rule).

Neste contexto, ganha relevo a questão de saber se os documentos estão ligados à prossecução do interesse público, ou se se trata de documentos privados protegidos pelo direito. No caso Fisher v. United States, o Supremo Tribunal sustentou que o mesmo abrange apenas a comunicação testemunhal incriminatória e não a prova documental $^{19}$. O facto de os documentos solicitados incriminarem um contribuinte, por exemplo, não significa que a obrigação de proceder à sua entrega viole, só por si, o direito à não auto-incriminação.

No entanto, na sua decisão no United States v. Doe, o Supremo Tribunal sustentou que isso poderá não acontecer se se tratar de documentação contendo aspectos testemunhais e efeito incriminatório, o que não é o caso quando se obriga o arguido a

${ }^{14}$ Blau v. United States, 340 U.S. 159, 71 S. Ct. 223, 95 L. Ed. 170 [1950].

${ }^{15}$ Hoffman v. United States, 341 U.S. 479, 71 S. Ct. 814, 95 L. Ed. 1118 [1951].

${ }^{16}$ Curcio v. United States, 354 U.S. 118, 77 S. Ct. 1145, 1 L. Ed. 2d 1225 [1952].

${ }_{17}$ Stephen A. Saltzburg The Required Records Doctrine: Its Lessons for the Privilege Against Self-Incrimination, 53, University of Chicago Law Review, 1986, 6 ss. e 24 ss.

${ }^{18} 335$ US 1 (1948).

${ }^{19} 425$ US 391 (1976), 408, 409. Veja-se, na doutrina, Charles Gardner Geyh, The Testemonial Component of the Right Against Self-Incrimination”, 36, Catholic University Law Review, 1987, 611 ss. 
autorizar os bancos estrangeiros a procederem à divulgação das contas bancárias abertas em seu nome ${ }^{20}$.

A suprema instância dos Estados Unidos considerou que no caso Fisher o relevo testemunhal assumido pelo fornecimento de documentos pelo contribuinte à administração tributária seria mínimo, o mesmo sucedendo com o efeito auto-incriminador. Ou seja, de acordo com esta orientação jurisprudencial, sempre que o fornecimento de documentos, por ordem da administração, tiver um relevo testemunhal e um impacto auto-incriminatório, o mesmo é precludido pelo direito à não auto-incriminação. O relevo testemunhal dos documentos afere-se pelo respectivo conteúdo informativo, isto é, pela quantidade de informação factual nova que transmitem à Administração.

No mencionado caso United States v. Doe, tratava-se apenas de um documento autorizando a divulgação pelos bancos da eventual existência de contas bancárias em nome da parte recorrente, sem qualquer conteúdo informativo. Reconhece-se, assim, que, ao menos nalguns casos, o fornecimento de documentos pode ter valor testemunhal, declarativo e comunicativo, bem como confirmar a existência, posse e autenticidade do documento a fornecer. Quando seja esse o caso, o direito à não auto-incriminação pode ser invocado de forma bem sucedida. Por esta forma pretende-se reagir contra ordens administrativas de conteúdo muito genérico em que se solicite, do visado, a produção de documentos cuja existência não era certa. Desse modo, procura-se limitar o poder da Administração de forçar o contribuinte a confessar a existência dos documentos ${ }^{21}$.

A primeira vez que o Supremo Tribunal norte-americano decidiu acerca da sua eventual aplicação às empresas, foi num caso de 1886, o caso Boyd v. United States ${ }^{22}$. Aqui o Governo tentou forçar o senhor Boyd a produzir documentos incriminatórios, tendo sido contrariado por aquele tribunal superior, que perfilhou um entendimento amplo do direito à não auto-incriminação, declarando que: "any compulsory discovery ... to convict [a party] of a crime, or to forfeit his property, is contrary to the principles of free government." Também aqui se considerou a possibilidade de documentos pessoais poderem ter um valor preponderantemente testemunhal, estando por isso a coberto do direito à não auto-incriminação $0^{23}$.

Ou seja, tendo por base, quer a Quinta Emenda, quer o direito de protecção contra buscas e apreensões irrazoáveis, o Supremo Tribunal norte-americano estabeleceu um

\footnotetext{
${ }^{20}$ United States v. Doe 465 US 605, 613. Acresce que se considera que os bancos estrangeiros não podem invocar a Quinta Emenda para se recusarem a divulgar as contas. Braswell v. United States, ante, at 102-103; Bellis v. United States, 417 U.S. 85, 89 -90 (1974).

${ }^{21}$ Samuel A. Alito, Jr, “Documents and the Privilege Against Self-Incrimination”, 48 University of Pittsburgh Law Review, 1986, 27 ss., onde já se criticava a posição do tribunal por causa da incerteza jurídica e das dificuldades práticas que gera.

${ }^{22} 116$ U.S. 616, 1886.

${ }^{23}$ Nas palavras do tribunal, [W]e are unable to perceive that the seizure of a man's private books and papers to be used in evidence against him is substantially different from compelling him to be a witness against himself.” Boyd v United States 116 US 616, 627-30 (1886). Veja-se, sobre os desenvolvimentos subsequentes noutros domínios do direito penal, Jonathan M. Rund, "McKune V. Lile: Evisceration of the Right Against Self-incrimination Through The Revival of Boyd V. United States”, 12 George Mason Law Review, 2003, 409 ss.
} 
precedente fortemente defensor dos direitos e garantias. Refira-se, apenas, que este entendimento viria mais tarde a ser limitado pelo caso Andersen v Maryland, tendo o Supremo Tribunal colocado o acento tónico, não apenas no carácter publico ou privado dos documentos, mas também na questão de saber se o respectivo conteúdo foi fornecido de forma voluntária ou sob coacção ${ }^{24}$. Isto de forma a reconduzir ao âmbito de protecção do direito à não auto-incriminação apenas o testemunho prestado sob coacção. Considera-se que o fornecimento de documentos, por oposição às situações em que existe um mandato de apreensão, pode ter um valor comunicativo de natureza testemunhal.

Alguns anos depois do caso Boyd v. United States foi decidido um outro caso, designado por Hale v. Henkel $^{25}$, tendo-se verificado um retrocesso nesta orientação jurisprudencial, tendo a doutrina da "collective entity" sido utilizada pelo Supremo Tribunal norte-americano para rejeitar a aplicação da Quinta Emenda às empresas, com base nos seguintes argumentos:

I) Pelo facto de as empresas serem uma criação jurídica do Estado ("legal creature of the state”), destituídas de alma, sentimentos e pensamentos, elas devem estar sujeitas ao poder de investigação do Estado que as criou, com base nos chamados "visitatorial rights" que cabem ao Estado ${ }^{26}$;

II) $\mathrm{O}$ direito à não incriminação é um direito pessoal, que não pode ser atribuído a outros intervenientes, nem mesmo a empresas em que a principal testemunha seja um dos empregados. O tribunal sublinhou que existe uma clara distinção entre um empregado, que pode reivindicar este direito, e a empresa em si mesma, que não pode;

III) Se os trabalhadores de uma empresa pudessem recusar a entrega de livros e outros documentos relativos à empresa, invocando como motivo da recusa o desejo de não incriminar a empresa, este comportamento daria azo ao fracasso de muitos processos contra as ditas empresas em que toda a acusação assenta sobre os referidos documentos. Para evitar este resultado impõe-se a proibição da aplicação às empresas do direito à não incriminação, porque em certas situações, diz-se, os fins justificam os meios.

Mesmo rejeitando a aplicação do princípio às empresas, restava a questão de saber se o direito à não auto-incriminação se aplica aos representantes das empresas que se neguem a entregar documentos que os poderiam incriminar. E o Supremo Tribunal tem reiteradamente entendido que não só é admissível a aplicação de "subpoenas" (ordem para comparecer num determinado local, a uma determinada hora para prestar declarações sobre um assunto de interesse governamental) a estas pessoas, como também que os documentos poderão ser utilizados contra elas em tribunal. Este princípio, estabelecido pela decisão Hale, ficou conhecido como "collective entity rule”.

${ }^{24} 427$ US 463 (1976)

${ }^{25} 201$ U.S. 43, 1906.

${ }^{26}$ Todavia, o tribunal acabou por mais tarde recusar a aceitação deste direito do Estado, no caso Braswell v. United States, 487 U.S. 99, 106 (1988) 
À luz deste princípio, uma corporação não goza, em si mesma, do direito à não auto-incriminação. De onde resulta que alguém que tenha a guarda dos documentos da empresa não pode recusar o seu fornecimento, com base no seu privilégio individual, mesmo que daí resulte a sua incriminação pessoal. Isto, porque se entende que quem guarda esses documentos age em nome da empresa, tendo por isso o dever de prestar esses documentos se a isso for solicitado ${ }^{27}$. A entrega dos documentos não é, neste caso, um acto pessoal, mas um acto da pessoa colectiva em presença, que, como dissemos, não goza do direito à não auto-incriminação.

Esta leitura restritiva dos direitos das sociedades comerciais (corporations) merece uma apreciação dividida da doutrina. Alguns autores sustentam que a extensão do direito à não auto-incriminação às pessoas colectivas, fazendo com que estas beneficiem dos direitos humanos, é uma "anomalia jurídica" que serve o interesse de ocultação das infracções societárias, pondo em causa os direitos de soberania regulatória do Estado e prejudicando a tutela dos interesses do público em geral ${ }^{28}$. De acordo com este entendimento, o direito à não auto-incriminação é, acima de tudo, um direito de proteç̧ão do indivíduo vulnerável diante do risco de utilização abusiva dos poderes do Estado.

Alguma doutrina sustenta que este entendimento não se aplica às grandes empresas, com maior capacidade de resistência ao exercício do poder estadual, mas apenas aos indivíduos. Assim é, sustenta-se, porque a aplicação do direito à não auto-incriminação às pessoas colectivas poderia inviabilizar a investigação estadual das infracções cometidas pelas pessoas colectivas de grande dimensão e muito poderosas, comprometendo a tutela de bens fundamentais da comunidade e do Estado. Além do mais, essa extensão iria contra a tendência crescente, sustentada pelo "corporate constitutionalism" ${ }^{29}$, no sentido de aumentar a transparência e a responsabilidade pública das pessoas colectivas de grande dimensão, equiparando-as as autoridades públicas ${ }^{30}$.

Em sentido diametralmente oposto, alguns autores têm vindo defender que mesmo as pessoas colectivas têm o direito a ser tratadas com dignidade e com justiça, sendo que também as pessoas colectivas têm um nome, um bom nome e uma reputação a defender, dimensões indissociáveis do seu valor de mercado ${ }^{31}$. Contesta-se, assim, a leitura restritiva dada aos direitos das pessoas colectivas, chamando a atenção para a necessidade de proteger os direitos e os interesses dos indivíduos a elas associados, sustentando uns a aplicação dos direitos fundamentais às pessoas colectivas ${ }^{32}$ e

${ }^{27}$ Braswell v. United States, 487 U.S. 99, 105, 110, (1988)

${ }^{28}$ Lucien J. Dhooge, “Human Rights for Transnational Corporations”, Journal of Transnational Law \& Policy, 16, Spring 2007, p. 197.

${ }^{29}$ Stephen Bottomley, "From Contractualism to Constitutionalism: A Framework for Corporate Governance", Sidney Law Review, 17, 1997.

${ }^{30}$ T. Donaldson \& T. W. Dunfee, Ties That Bind: A Social Contracts Approach to Business Ethics, 1999; Neste sentido, Patricia Nassif Fetzer, "The Corporate Defamation Plaintiff as First Amendment "Public Figure": Nailing the Jellyfish”, Iowa Law Review, 68, 1982, p. 35, 85.

${ }^{31}$ Richard Smith, "Stealing the Good Name of the Company: The Fourth Circuit Strengthens Constitutional Barriers for Corporate Defamation Plaintiffs”, Iowa Journal of Corporation Law, 24, 1999, p. 727 ss

${ }^{32}$ Carl J. Mayer, "Personalizing the Impersonal: Corporations and the Bill of Rights", Hastings Law Journal, 41, 1990, p. 577, 580 ss.; Lisa Magee Arent, “A Matter of "'Governing Importance'": Providing Business Defamation and Product Disparagement Defendants Full First Amendment Protection”, Indiana Law Journal, 67, 1992, p. 441 ss. 
apelando à criação de um catálogo de direitos fundamentais das pessoas colectivas ${ }^{33}$.

De acordo com este entendimento, a recusa da protecção dos direitos fundamentais das pessoas colectivas empresariais, enquanto aglomerados de indivíduos sujeitos a um esquema funcional de cooperação económica, conduz, por arrastamento, à violação dos direitos fundamentais dos indivíduos funcionalmente associados à empresa, na qualidade de administradores ou trabalhadores ${ }^{34}$. Alguns autores mobilizam ainda 0 argumento do equilíbrio de poderes, na relação entre os Estados e as empresas, para justificar a garantia do direito à não auto-incriminação às grandes empresas ${ }^{35}$.

A esta luz, a imposição de sanções à empresa pode repercutir-se negativamente na capacidade que os indivíduos têm de sustentar os seus agregados familiares, ameaçando dessa forma a possibilidade de exercício de muitos direitos fundamentais de natureza económica, social e cultural dos indivíduos e dos membros dos respectivos agregados familiares ${ }^{36}$.

Mas além deste impacto indirecto da violação dos direitos fundamentais da pessoa colectiva no exercício dos direitos fundamentais dos indivíduos dela directa ou indirectamente dependentes, os autores apontam uma ligação directa entre a tutela do direito à não auto-incriminação da pessoa colectiva e o mesmo direito dos seus funcionários. Como exemplo de um modo de ligação que não pode acontecer, os autores alertam para o caso Bellis v United States ${ }^{37}$, em que uma concepção restritiva do direito à não auto-incriminação das pessoas colectivas acabou por conduzir a uma leitura restritiva do mesmo direito relativamente a indivíduos a elas associados ${ }^{38}$. Neste caso, o Supremo Tribunal sustentou que "[a]n individual cannot rely upon the privilege to avoid producing the records of a collective entity which are in his possession in a representative capacity, even if these records might incriminate him personally.”

\subsubsection{Desenvolvimentos mais recentes}

Os casos mediáticos da falência das empresas Emron, do sector energético, e Arthur Anderson, de auditoria financeira, tiveram como consequência uma verdadeira

\footnotetext{
${ }^{33}$ George Ellard, "Making the Silent Speak and the Informed Wary, American Criminal Law Review, 42, 2005, p. 985/991 - A abolição da garantia de não auto-incriminação é típica de processos inquisitórios, e o autor diz que os EUA estão a caminhar para um processo deste tipo; John F. Lauro, "Protecting Corporate Employees: The Need for a New Bill of Rights”, New York Law Journal, 17, April, 2006, p. 4, em que se propõe a criação de um catálogo de direitos fundamentais para as empresas (Corporate Employees Bill of Rights).

${ }^{34}$ Esta corrente conhece um argumento adicional a partir da dogmatica europeia de direitos fundamentais, em que se considera que, se mesmo as pessoas colectivas públicas podem, nalguns casos, ser titulares de direitos fundamentais, quando a sua actividade seja indissociavelmente ligada à realização de direitos fundamentais dos indivíduos, o mesmo valerá, por maioria de razão, no caso das pessoas colectivas privadas, mesmo se às mesmas se apliquem exigências reforçadas de "good governance".

${ }^{35}$ Scott A. Trainor, “ A Comparative Analysis of a Corporation’s Right Against Self-Incrimination”, 18, Fordham International Law Journal, 1995, 2139 ss.

${ }^{36}$ Tara J. Radin, “700 Families to Feed: The Challenge of Corporate Citizenship”, Vanderbilt Journal of Transnational Law, 36, 2003, p. 619 ss.

${ }^{37} 417$ US 88 (1974).

${ }^{38}$ Peter J. Henning, "Finding What Was Lost: Sorting Out the Custodian's Privilege Against Self-Incrimination from the Compelled Production of Records”, 77, Nebraska Law Review, 1998, 34 ss., sustentando que o facto de alguém representar uma empresa não pode significar que o mesmo renuncia, por esse facto, aos seus direitos fundamentais.
} 
revolução paradigmática no âmbito da "corporate governance” 39 .

Nesse contexto, o governo de George W. Bush tomou medidas severas no sentido de combater a fraude financeira e restaurar a confiança pública na integridade dos mercados. Assim, foram produzidos dois Memorandos que tocam esta questão. O memorando Thompson apareceu em primeiro lugar, procurando fornecer "guidelines" aos "federal prosecutors" que tratam de crimes relacionados com empresas. O memorando Thompson coloca grande ênfase na cooperação das empresas com a investigação $^{40}$. O memorando McNulty continuou esta tendência.

Em todo o caso, apesar de salientarem a importância da supervisão das empresas e de apontarem para um reforço do controlo das mesmas por parte das autoridades reguladoras, ambos partilham, como principio geral, a regra de que as sociedades não podem ser tratadas de forma mais branda nem mais severa por causa da sua natureza artificial "[corporations should not be treated leniently because of their artificial nature, nor should they be subject to harsher treatment]." De acordo com este entendimento, as garantias que são asseguradas às pessoas singulares devem igualmente ser asseguradas às sociedades ${ }^{41}$. Esta ideia, porém, não pode levar a esquecer que uma parte significativa da doutrina tem alertado para o facto de estes memorandos pretenderem introduzir uma deriva inquisitorial no processo penal, abandonando a estrutura acusatória constitucionalmente consagrada ${ }^{42}$.

Por seu lado, a recente crise financeira no mercado de crédito hipotecário de alto risco, com as suas implicações nos Estados Unidos (v.g. Bear Sterns, Lehman Brothers, AIG) e no resto do mundo, veio dar alento à perspectiva daqueles que vinham sustentando a necessidade de uma mais intensa supervisão por parte das entidades reguladoras. Foi precisamente neste contexto que se intensificou a ênfase, por parte da doutrina, na necessidade de preservação e mesmo de reforço das garantias procedimentais e processuais das sociedades comerciais em actividades reguladas.

Se uma acção cria sempre uma reacção, a intensificação do controlo por parte das entidades reguladoras levou a doutrina a chamar a atenção para os riscos de uma sobre-aplicação (overenforcement) das normas aplicáveis às actividades reguladas. É que, este contexto de maior intensificação da regulação sobre as empresas torna mais fácil a respectiva sujeição a um tratamento procedimental e processualmente inaceitável e a pressões no sentido do fornecimento de depoimentos, de natureza testemunhal, destituídos de fidedignidade e passíveis de serem falsamente incriminatórios. Esta linha de pensamento volta a colocar o acento tónico nos riscos de abuso de poder coercivo sobre as grandes empresas, o qual, como vimos, esteve na base do direito à não auto-incriminação.

${ }^{39}$ Scott Harshbarger, Goutam U. Jois, "Looking Back and Looking Forward: Sarbanes-Oxley and the Future of Corporate Governance”, Akron Law Review, 40, 2007, p. 1 ss, Robert Monks, Nell Minow, Corporate Governance, (3th edition), Malden, 2004.

${ }^{40}$ Sobre este memorando, Ellard, Making the Silent Speak and the Informed Wary..., cit., 985 ss.

${ }^{41}$ Sobre este memorando, vide Christopher A. Wray, Robert K. Hur, "The State Of Federal Prosecution: Article: Corporate Criminal Prosecution In A Post-Enron World: The Thompson Memo In Theory And Practice”, American Criminal Law Review, 45, 2006, p. 1095 ss.

${ }^{42}$ Ellard, Making the Silent Speak and the Informed Wary..., cit., 991 ss. 
Assim, os desenvolvimentos doutrinais mais recentes têm sustentado que dificilmente se poderá justificar a privação de direitos fundamentais às pessoas colectivas pelo simples facto de o serem. De acordo com este entendimento, em matéria de direitos e deveres fundamentais as pessoas colectivas devem ser consideradas titulares dos direito fundamentais compatíveis com a sua natureza. Assim deve ser, por várias razões.

Em primeiro lugar, as pessoas colectivas não são apenas uma abstracção ou uma ficção jurídica criada pelos ordenamentos jurídicos dos Estados nem um simples aglomerado de bens. Do ponto de vista material, elas são um conjunto de pessoas individuais que colaboram na prossecução de finalidades comuns, em muitos casos de natureza económica. Pelo que tudo o que sucede à empresa afecta as pessoas directamente e indirectamente envolvidas (v.g. accionistas, administradores, trabalhadores, clientes, fornecedores, famílias), como acima se salientou.

Daí que a negação de direitos de defesa a uma pessoa colectiva possa ter um impacto negativo na vida das pessoas com ela relacionadas. A aplicação de sanções a uma empresa é susceptível de causar danos a indivíduos que não são individualmente responsáveis pela infracção. Daí que deva haver o máximo cuidado em assegurar às empresas todas as garantias de defesa. De acordo com este entendimento, os direitos das pessoas colectivas em processos sancionatórios não podem ser sacrificados por razões de mera política contraordenacional ou penal ${ }^{43}$. Refira-se, que mesmo no contexto da jurisdição internacional, nomeadamente quando esteja em causa a responsabilidade dos Estados, a estes são dadas garantias de processo equitativo, na medida em que as mesmas resultem da essência de um julgamento justo.

Em segundo lugar, as empresas, apesar da sua dimensão, podem apresentar fragilidades, em matéria de direitos de defesa, quando comparadas com uma pessoa singular. A doutrina tem chamado a atenção para o facto de que, embora todos os processos criminais possam ser permeáveis a influências externas, a verdade é que os processos contra empresas são particularmente susceptíveis a este tipo de pressões, tendo em conta, nomeadamente, o estatuto algo ambíguo da figura das pessoas colectivas, a dificuldade em investigar as empresas, a sua importância central para a economia, a teia de relações que mantêm com empregados e accionistas e a especial posição de vulnerabilidade que podem chegar a ter no mercado e diante da opinião pública. Tudo isto torna a posição das empresas muito sensível, sendo que a sujeição às pressões do mercado pode ter como consequência que a simples instauração de um processo sancionatório pode constituir uma ameaça à sua sobrevivência ${ }^{44}$.

É evidente que, num contexto regulatório, as empresas reguladas encontram-se sujeitas a deveres de informação e colaboração, sem os quais o exercício da função de regulação e supervisão seria impossível. É igualmente evidente que o exercício

${ }^{43}$ Assim, o juiz Kennedy, no caso Braswell (Braswell v. United States, 487 U.S. 99, 119 (1988) (Kennedy, J., dissenting) "[T]he privilege against self-incrimination does not permit balancing the convenience of the Government against the rights of a witness."

${ }^{44}$ Bharara, Preet, "Corporations Cry Uncle And Their Employees Cry Foul: Rethinking Prosecutorial Pressure On Corporate Defendants”, American Criminal Law Review, 44, 2007, p. 70 ss. 
dessa função é essencial à protecção de um conjunto de bens jurídicos de relevo constitucional e legal. Os desenvolvimentos mais recentes da "corporate governance" e do "corporate constitutionalism" tendem a aproximar os deveres de transparência, boa governação, responsabilidade social e prestação de contas das grandes empresas reguladas aos seus congéneres estaduais, tendo em vista o grande impacto que a sua actividade exerce sobre o interesse público. E trata-se de desenvolvimentos geralmente considerados como positivos e desejáveis no quadro da economia global.

Daí que a prestação de documentos num contexto regulatório, e a sua posterior utilização em processos sancionátorios, de natureza contraordenacional e penal, não fira, por si só, o princípio da não auto-incriminação. O problema pode colocar-se, porém, no caso de existir uma pressão inadmissível, por parte das autoridades, no sentido de levar as empresas a sentirem-se coagidas a cooperar, devido à sua falta de opções e vulnerabilidade. Um grau razoável de pressão por parte das autoridades é praticamente inevitável, num contexto sancionatório. O problema consiste em saber quando é que essa pressão é excessiva.

Em terceiro lugar, salienta-se os riscos associados ao facto de o Estado pretender depender cada vez mais, quando não exclusivamente, das empresas para a investigação das infracções por elas alegadamente cometidas. Embora se reconheça que as empresas reguladas têm um dever qualificado de transparência, também se teme que o exercício de uma pressão excessiva por parte do Estado possa levar a que estas se sintam pressionadas a exercer um controlo desmesurado sobre administradores, accionistas e trabalhadores, podendo criar um clima de vigilantismo censório e intimidatório, inaceitável do ponto de vista da protecção sustentada dos respectivos direitos fundamentais. De acordo com este entendimento, a investigação é essencialmente uma tarefa estadual, não cabendo ao Estado pressionar as empresas a testemunharem contra si próprias. Tal pode acontecer se a pressão exercida sobre as empresas as colocar numa situação de vulnerabilidade diante do mercado, a ponto de as mesmas optarem por confessar infracções não cometidas apenas para sacudir a pressão regulatória.

Como se disse, a doutrina mais recente tem sustentado que tendência actual no sentido do reforço do controlo e da supervisão das instituições de crédito tem que ser compensada pela expansão do elenco das respectivas garantias processuais, em domínios como as relações privilegiadas entre cliente e advogado e o princípio da não incriminação ${ }^{45}$. Com isto de modo algum se pretende minimizar a importância das obrigações de transparência por parte das empresas reguladas. Pretende-se apenas garantir um justo equilíbrio e a concordância prática entre bens jurídicos em colisão, de maneira a impedir que a tutela de finalidades constititucionalmente legítimas seja levada a cabo mediante a preterição de importantes dimensões garantísticas.

\subsection{Outros países anglo-americanos}

Se os Estados Unidos se têm manifestado relutantes a aceitar a aplicação do direito à não auto-incriminação às pessoas colectivas, embora com objecções crescentes de

\footnotetext{
${ }^{45}$ Richard A. Bierschbach \& Alex Stein, “Overenforcement”, Georgetown Law Journal, 93, 2005, p. 1743.
} 
uma boa parte da doutrina, já a questão não tem tido resposta unânime noutros Estados de matriz anglo-saxónica, como sejam o Reino Unido, o Canadá, a Nova Zelândia e a Austrália. Nas linhas que se seguem daremos conta dos aspectos essenciais que o debate jurisprudencial tem conhecido nestes Estados.

\subsubsection{Reino Unido}

No Reino Unido, a garantia do direito à não auto-incriminação às pessoas colectivas corresponde à orientação dominante, sendo os desvios à mesma prontamente criticados pela doutrina. Assim, abandonou-se a ideia de que as pessoas colectivas, por não terem corpo e alma, não podem ser titulares de direitos fundamentais, sendo hoje consensual que podem ser afectadas na sua dignidade e reputação e objecto da aplicação de sanções ${ }^{46}$.

Por exemplo, uma decisão do Tribunal da Ilha de Man no caso Re Atrium Trading Ltd. (in liquidation), Garret and Others ${ }^{47}$, pronunciou-se sobre a intenção da entidade reguladora no sector financeiro (Financial Supervision Commission) de investigar a companha Atrium Trading Ltd., ao abrigo da secção $14^{\circ}$ do Banking Act, de 1998. Qualquer pessoa que seja convocada a prestar declarações ao abrigo desta disposição encontra-se protegida pelo direito à não auto-incriminação, embora cometa uma infracção se se recusar a cooperar ou prestar informações falsas. No caso, o Tribunal de Apelação sustentou que os directores são protegidos pelo direito à não auto-incriminação, mas não a pessoa colectiva propriamente dita.

Contestando esta decisão, Philip Joseph ${ }^{48}$ sustentou que a mesma violou os mais básicos princípios do direito das empresas, na medida em que a secção 14(6) do Banking Act de 1998, deve ser interpretada como protegendo também o direito à não auto-incriminação das pessoas colectivas, já que a referência que a disposição faz às pessoas ("persons”) deve ser entendida em sentido amplo. Assim é, na medida em que, por um lado, os directores actuam como representantes da empresa, funcionando como uma sua espécie de alter ego. Quando eles falam, ou se abstêm de o fazer, eles agem em nome e no interesse da empresa ${ }^{49}$.

Por outro lado, se não estender esta protecção às pessoas colectivas, as mesmas ficam processualmente desprotegidas. Se uma pessoa colectiva não for protegida quando um dos seus representantes é chamado a revelar informações, a mesma nunca é protegida e provas contra ela apresentadas pelos seus directores seriam sempre admissíveis. Para Philip Joseph, quando a Financial Supervision Commission notificou os directores da empresa para prestarem declarações com base na secção 14 do Banking Act de 1998, o objectivo prosseguido pela entidade de supervisão era o da investigação da empresa, devendo por esse motivo a protecção contra a auto-incriminação, concedida

\footnotetext{
${ }^{46}$ British Steel v Granada Television [1981] AC 1096, 1127. Nas palavras de Lord Denning, "[I]n these Courts, as in the United States, the privilege is not available to a corporation. It has no body to be kicked or soul to be damned".

${ }^{47}$ 2DS 2001/32 I

${ }^{48}$ Philip Joseph, "Self-Incrimination and Retrospectivity", Law Quarterly Review, vol. 120, July 2004, p. $378 / 382$

${ }^{49}$ Assim se pronunciou a jurisprudência britânica, no caso Salomon v. Salomon \& Co. [1897] A. C. 22.
} 
pela secção 14, ser interpretada de forma a abranger, quer os representantes da empresa Atrium Trading Lda., quer a empresa em si mesma.

Importa salientar que a decisão proferida no caso Atrium Trading Ltd. vai contra a orientação dominante nas demais jurisdições do Common Law. Por exemplo, no caso Triplex Safety Glass Co. Ltd v Lancegaye Safety Glass ${ }^{50}$, o Tribunal de Apelação inglês sustentou que se as pessoas colectivas podem ser sujeitas a responsabilidade criminal, então as mesmas também devem ser protegidas contra o terem que confessar um crime.

Este caso Triplex é considerado um leading case no domínio da extensão do direito à não auto-incriminação às pessoas colectivas. No mesmo sentido, a Câmara dos Lordes havia sustentado, no caso Rio Tinto Zinc Corporation v Westinghouse Electric Corporation ${ }^{51}$, que o direito à não auto-incriminação das pessoas colectivas não pode ser subvertido através da obrigação dos seus directores de apresentarem provas contra elas, sob pena de o mesmo perder qualquer sentido útil. Convém salientar, porém, que este entendimento não tem sido aceite sem controvérsia no Reino Unido, dadas as implicações daí decorrentes para a investigação das actividades ilícitas praticadas pelas pessoas colectivas.

\subsubsection{Canadá}

No Canadá, o direito à não auto-incriminação das pessoas colectivas foi revogado, não se aplicando às pessoas colectivas a imunidade testemunhal consagrada na secção 5 do Evidence Act, de 1985. O mesmo sucede com o direito ao silêncio consagrado nas secções 11(c) e 13 da Carta de Direitos Fundamentais ${ }^{52}$. Por seu lado, o Supremo Tribunal do Canadá entendeu, no caso Thomson Newspapers Ltd. V. Director of Investigation and Research ${ }^{53}$, que uma decisão nesta matéria deve apoiar-se na distinção entre "prova prova testemunhal que o arguido foi obrigado a criar" e "prova com existência independente que o arguido foi compelido a ajudar a localizar, a identificar ou a explicar”. De acordo com esta instância judicial, só no primeiro caso é que se estaria perante material probatório de utilização proibida pelo direito à não auto-incriminação. Pelo contrário, considera-se não existir nada de inerentemente injusto na utilização de provas que poderiam ter sido descobertas sem recurso a poderes coercivos e cuja qualidade e conteúdo permanecem independentes do recurso a poderes coercivos ${ }^{54}$.

\subsubsection{Nova Zelândia}

Na Nova Zelândia, o direito à não auto-incriminação pode ser invocado, prima facie, em resposta a questões ou a pedidos de prestação de documentos, sejam estes pré-existentes ou criados no momento do pedido ${ }^{55}$. No entanto, o direito não pode ser

\footnotetext{
50 (1934) Ldt. 19392 K. B. 395. Sobre este caso, Lynn Loschin, “A Comparative Law Approach to Corporations and the Privilege Against Self-Incrimination”, 30, U.C. Davis Law Review, 1996, 260 ss.

${ }^{51}$ (1978), A.C. 547.

${ }^{52} R$ v Amway Corp (1989) 56 DLR (4th) 309 and B C Securities Commission v Branch (1995) 123 DLR (4th) 462 (SCC).

5354 C.C.C. 417 at 508.

${ }^{54}$ Veja-se, ainda, Reg. v. Bank of Montreal (1962) 36 D.L.R.2d 45 (Can.).

${ }^{55}$ Taranaki Co-operative Dairy Co Ltd v Rowe [1970] NZLR 895, 901.
} 
invocado quando se trate da recolha de provas materiais (v.g. exposição da face, amostras de sangue, impressões digitais, armas $)^{56}$.

Também aqui, ao que parece, o fornecimento de documentos só se encontrará protegido pelo direito à não auto-incriminação quando não estiver coberto por um mandato de busca e apreensão e assumir um relevo testemunhal preponderante. Isto, no pressuposto de que os documentos individuais são uma extensão da mente e do pensamento do indivíduo. A protecção dos documentos surge, assim, no contexto da protecção da privacidade. Daqui decorre, sem prejuízo do que acima se disse, uma maior relutância à aplicação do direito à não auto-incriminação quando estejam em causa documentos pré-existentes. E isto, por várias razões.

Desde logo, porque no momento da produção de documentos não se verificou o recurso à coacção, não existindo, por isso, um risco atendível de abuso de poder. Além disso, porque a pré-existência de documentos atenua o risco do pronunciamento de palavras irreflectidas, por parte de pessoas inocentes, no contexto de uma investigação. Ou seja, existe uma maior probabilidade de os documentos pré-existentes serem confiáveis, do ponto de vista probatório. A isto acresce, que o acesso a documentos pré-existentes já se encontra devidamente limitado e regulado pelas normas respeitantes às revistas, buscas e apreensões ${ }^{57}$.

O direito à não auto-incriminação já se aplicará no caso de documentos produzidos no momento em que é solicitado o seu fornecimento (v.g. confissões filmadas ou escritas), desde que a sua produção esteja dependente de um pedido específico formulado pelo investigador (v.g. documentos elaborados em contextos regulatórios; documentos elaborados para ocultar provas) ${ }^{58}$.

Relativamente à questão da aplicação do direito à não auto-incriminação às pessoas colectivas, os tribunais da Nova Zelândia têm sustentado que se o promotor (prosecution) pode apresentar provas contra uma empresa através das afirmações dos seus directores proferidas fora do tribunal, é razoável que a empresa possa invocar o seu direito à não auto-incriminação quando fala através deles ${ }^{59}$. Esta orientação apoia-se na observação das diferenças relevantes que se estabelecem entre as pessoas colectivas, com especial relevo às que se dedicam à actividade empresarial, e as pessoas físicas ${ }^{60}$.

Desde logo, as pessoas colectivas não podem ser sujeitas a penas privativas da liberdade. Além disso, embora as pessoas colectivas não podem fornecer provas são obrigadas a fazê-lo através dos seus administradores ou trabalhadores. Do mesmo modo, as pessoas colectivas têm responsabilidade limitada, pelo que se alguma quantia monetária lhes for exigida quem por elas responde são os seus sócios. Acresce que as pessoas colectivas estão sujeitas a sanções pecuniárias mais elevadas do que os

${ }^{56}$ Sorby $v$ Commonwealth (1983), 46 ALR 237, 244

${ }^{57}$ S 21, New Zealand Bill of Rights Act, 1990.

${ }^{58}$ New Zealand Law Commission, “The Privilege Against Self-Incrimination”, September Wellington, New Zealand, 1996, p. 60 ss.

${ }^{59}$ Nestes termos, New Zealand Apple \& Pear Marketing Board v Master \& Sons Ltd. [1986] 1 N. Z. L. R. 191, 196.

${ }^{60}$ New Zealand Law Commission, “The Privilege Against Self-Incrimination”, cit., p. 65 ss. 
indivíduos, podendo ser seriamente afectadas se o montante das sanções impostas exceder os seus activos. Finalmente, as pessoas colectivas operam através de terceiros, como sejam os administradores ou os trabalhadores, e com eles e partilham informações.

\subsubsection{Austrália}

A questão tem sido igualmente discutida na Austrália. A orientação dominante tende a desvalorizar a possibilidade de o direito à não auto-incriminação ser invocado pelas pessoas colectivas. Nesse sentido milita a secção 187 do Evidence Act, de 1995.

Do mesmo modo, no âmbito do common law sustenta-se que o direito à não auto-incriminação não pode ser invocado por indivíduos relativamente ao fornecimento de documentos cuja propriedade pertence a outras pessoas colectivas, especialmente quando estas proibiram o seu fornecimento e este possa ser visto como uma violação das obrigações disciplinares e de lealdade institucional ${ }^{61}$.

Em todo o caso, o direito à não auto-incriminação tem sido invocado, de forma bem sucedida, por administradores de empresas para não serem obrigados a entregar documentos que não estão realmente na sua posse, mas sim na posse da pessoa colectiva proprietária dos documentos ${ }^{62}$.

Os tribunais australianos têm, além disso, reconhecido a possibilidade de invocação do direito à não auto-incriminação no contexto de processos sancionatórios de natureza administrativa ${ }^{63}$.

No contexto australiano é concedida uma atenção especial à decisão do Supremo Tribunal Australiano (High Court) no caso Environment Protection Authority v. Caltex Refining Company, de 24 de Dezembro de 1993, em que foi analisada a questão da aplicação do privilégio contra a não auto-incriminação às empresas ${ }^{64}$. Neste caso, o tribunal criminal de apelação (Court of Criminal Appeal) entendeu que o privilégio poderia ser aplicado às empresas por várias razões.

Em primeiro lugar, porque se uma empresa tem os deveres inerentes ao facto de ser cidadão de um país, então deve também gozar dos direitos correspondentes. Em segundo lugar, porque o direito à não auto-incriminação pretende realizar um equilíbrio entre os poderes do Estado e os direitos dos cidadãos, que também se justifica quanto às empresas. Em terceiro lugar, porque o privilégio ajuda a manter a integridade do sistema acusatório, obrigando o Estado a construir o caso contra o acusado antes de o forçar a responder às acusações.

Esta decisão foi revertida pelo High Court, que decidiu que o direito à não auto-incriminação não se aplicava às empresas, mesmo quando se trate da prestação

${ }^{61}$ Trade Practices Commission v Arnotts Ltd (1990) ATPR 41-010; Eccles \& Co v Louisville \& Nashville Railroad Co [1912] 1 KB 135

62 Estas indicações encontram-se no documento da New Zealand Law Commission, "The Privilege Against Self-Incrimination”, cit., p. 65 ss.

${ }^{63}$ Pyneboard [Pyneboard Pty. Ltd. v. Trade Practices Commission (1983) 45 A.L.R. 609] Sorby v. Commonwealth of Australia (1983) 46 A.L.R. 237;

${ }^{64}$ Caltex Refining Co Pty Ltd v. SPCC (1991) 25 NSWLR 118, 127. Norman M. Garland, “The Unavailability to Corporations of the Privilege Against Self-Incrimination: A Comparative Examination Based on EPA v. Caltex, High Court of Australia”, 16 New York Law School Journal of International \& Comparative Law, 1996, 55 ss. 
de testemunho oral. No entanto, a minoria vencida sublinhou alguns pontos importantes, cujo relevo substantivo para a discussão da questão permanece intacto. Desde logo, sublinhou-se que este direito tinha nascido como forma de luta contra os modelos inquisitoriais do processo penal, pelo que o mesmo se continua a justificar nos dias de hoje, mesmo para as empresas. Conclui-se, pois, que no contexto australiano ainda não existe uma posição totalmente estabilizada e consensual relativamente à aplicação do direito à não auto-incriminação às pessoas colectivas, embora se descortinem importantes argumentos nesse sentido.

\subsection{A jurisprudência do Tribunal Europeu dos Direitos do Homem}

Uma referência à jurisprudência do Tribunal Europeu dos Direitos do Homem (TEDH) é especialmente relevante, no contexto português, na medida em que o TEDH funciona, na prática, como uma espécie de super-tribunal constitucional europeu em matéria de direitos humanos. Na verdade, desde a última alteração ao Código de Processo Penal, de Setembro de 2007, que, no artigo 449\%1/g) deste diploma, se admite a revisão de uma sentença condenatória transitada em julgado sempre que a mesma seja inconciliável com uma decisão do TEDH ou que esta lance sérias dúvidas sobre a justiça da primeira.

Ou seja, para além da responsabilidade internacional do Estado português pela violação dos direitos humanos consagrados na $\mathrm{CEDH}$, admite-se agora a relativização do caso julgado por força de uma decisão daquela que é, cada vez mais, a suprema instância judicial europeia no âmbito dos direitos humanos. Daí que seja especialmente importante atender à jurisprudência do TEDH em matéria de direito à não auto-incriminação.

Esta jurisprudência permite encarar o direito à não auto-incriminação como algo mais do que um privilégio exclusivamente de matriz anglo-americana e situá-lo no contexto do direito internacional dos direitos humanos. Esta localização permite lançar mão do princípio da convergência dos direitos humanos, o qual aponta para a existência de uma estrutura unitária das restrições a estes direitos e dos limites a essas restrições.

Este contexto jusfundamental internacional é geralmente favorável à extensão dos direitos às pessoas colectivas. Na verdade, o TEDH tem sistematicamente sustentado a titularidade dos direitos humanos por pessoas colectivas (v.g. igrejas, órgãos de comunicação social, empresas), independentemente da sua forma. Embora o direito à não auto-incriminação não conste expressamente da linguagem aberta do artigo $6^{\circ}$ da $\mathrm{CEDH}$, ele tem vindo a ser densificado e concretizado ao longo dos anos, a partir das ideias combinadas de julgamento justo e processo equitativo.

O alcance normativo deste direito ainda se apresenta algo incerto, mas é já possível discernir uma tendência geral no sentido da sua ampliação. Nas linhas que se seguem procuraremos chamar a atenção para alguns dos casos em que o TEDH se tem confrontado com o sentido e os limites deste direito. Como veremos, existe um conjunto de casos em que o direito à não incriminação é objecto de uma consideração algo instável nos seus contornos precisos. Deles extraem-se algumas ênfases, cuja recondução a um todo consistente ainda se apresenta algo difícil de fazer. 
Merece desde logo referência o caso Funke v. France ${ }^{65}$, em que, depois de funcionários alfandegários terem encontrado alguns documentos na casa do senhor Funke, pediram-lhe que apresentasse outros documentos. Primeiro, ele aceitou. Mas depois negou-se e foi condenado ao pagamento de uma coima. O senhor Funke invocou o art. $6^{\circ} \mathrm{CEDH}$ e o TEDH acabou por lhe dar razão. O TEDH argumentou que os serviços alfandegários exigiram documentos cuja existência era incerta, não podendo por isso exigi-los, sob pena de violação do direito à não auto-incriminação implicitamente consagrado no artigo $6^{\circ}$ da $\mathrm{CEDH}$, mesmo que não pudessem ou não quisessem obtê-los de outro modo.

Isto, note-se, apesar de os documentos de que dispunham os serviços alfandegários apontarem para a existência dos documentos solicitados e do facto de o consentimento prontamente manifestado pelo Sr. Funke atestar a sua existência. Do mesmo modo, não ficou claro se os documentos obtidos foram posteriormente utilizados contra o senhor Funke num processo penal, facto que levou alguma doutrina a questionar sobre se se estaria realmente perante uma violação do artigo $6^{\circ}$ da $\mathrm{CEDH}^{66}$. Refira-se apenas que, neste caso, o queixoso invocou o art. $8^{\circ} \mathrm{CEDH}$, argumentando que as buscas a sua casa violavam o seu direito à privacidade, alegação que parece ter sido muito importante para o desfecho no caso junto do $\mathrm{TEDH}^{67}$.

No caso Saunders v. United Kingdom ${ }^{68}$, a Comissão Europeia dos Direitos Humanos avaliou a condenação de um responsável de uma sociedade comercial, a Guinness PLC, que tinha sido interrogado pela autoridade administrativa competente, o Department of Trade and Industry (DTI), em conexão com um esquema de manutenção artificial do preço das acções da Guinness PLC, utilizado para financiar a aquisição pública de outra sociedade, a Distillers Company PLC.

Enfrentando o risco de um processo penal, na sequência de uma investigação ao abrigo do Company Act de 1985, Saunders decidiu responder às perguntas de forma auto-incriminadora, tendo as suas respostas sido usadas contra ele em processo penal. De acordo com a jurisprudência nacional, os investigadores do DTI estariam autorizados a formular perguntas auto-incriminadoras, a compelir a resposta às mesmas e a transmitir os elementos assim obtidos às autoridades competentes para utilização em processos futuros.

A Comissão considerou como violadora do artigo $6^{\circ}$ da CEDH uma condenação baseada exclusivamente na prova obtida por auto-incriminação. De acordo com esta instância europeia, quem tem o ónus da prova é a entidade que acusa, pelo que não pode esta basear-se apenas nas provas obtidas através do testemunho oral do arguido ${ }^{69}$.

A Comissão entendeu que o direito à não auto-incriminação constitui uma dimensão essencial do direito do arguido a permanecer em silêncio, sendo um

65 (1993) 16 EHRR 297.

${ }^{66}$ Veja-se, por exemplo, Tim Ward, Piers Gardner, “The Privilege against Self-Incrimination: In Search of Legal Certainty”, European Human Rights, Issue 4, 2003, p. 391.

${ }^{67}$ Tim Ward, Piers Gardner, “The Privilege against Self-Incrimination...”, cit., p. 398.

${ }^{68}$ App. N ${ }^{\circ}$ 19187/91, EHRR, 313 (1996).

${ }^{69}$ Sobre este caso, Marc Berger, “Europeanizing Self-Incrimination...”, cit., p. 344. 
importante elemento de salvaguarda dos indivíduos contra a opressão e a coacção. Este direito está intimamente relacionado com o princípio da presunção da inocência e aplica-se a todos os tipos de crimes, incluindo fraudes empresariais complexas.

No entanto, a Comissão Europeia dos Direitos Humanos considerou que esta orientação jurisprudencial não abrange os elementos recolhidos, mesmo de forma compulsória, que tenham uma existência autónoma relativamente ao arguido, como sejam documentos, amostras de sangue e urina, ou outro material biológico para efeitos de testes de ADN.

Esta orientação jurisprudencial, embora não tenha por objecto central o exercício normal dos deveres de colaboração em contexto regulatório, parece caucionar a ideia de que se o Estado lança mão de um sistema compulsório de obtenção de informação no contexto regulatório, baseado na ameaça de sanções penais no caso de recusa a responder, não pode, mais tarde, servir-se da informação assim obtida para garantir uma condenação penal ${ }^{70}$.

Ou seja, inadmissível seria a posterior utilização da informação obtida em processo penal, e não o mero recurso a poderes coercivos. A violação do artigo $6^{\circ}$ da CEDH consumar-se-ia no momento da utilização da informação obtida em processo penal, pondo em causa a justiça do julgamento.

A este propósito, alguma doutrina observou que a orientação seguida pela Comissão e pelo TEDH visa, acima de tudo, evitar as designadas "expedições de pesca" (fishing expeditions) por parte das autoridades administrativas, estando a recusa da entrega de documentos incluída no artigo $6^{\circ}$ da $\mathrm{CEDH}$, sempre que se trate de documentos aos quais as autoridades não teriam acesso de outra forma, que não o serem entregues pelos próprios arguidos. No entanto, como vimos, a mesma tem um campo de aplicação bastante restritivo, deixando de fora a apresentação de documentos com base em mandato judicial em processo penal ${ }^{71}$.

E a verdade, é que na sua decisão IJL, GMR and AKP v. United Kingdom ${ }^{72}$, o TEDH sustentou que uma investigação, por parte da autoridade de comércio e indústria britânica, DTI, às infracções de uma sociedade comercial num contexto regulatório não cabia no âmbito normativo de infracção para efeitos do artigo $6^{\circ}$ da $\mathrm{CEDH}$, na medida em que os inspectores se limitavam a investigar e não a julgar, de algum modo, em matéria de forma ou de substância. O TEDH interpretou esse procedimento como preparatório da intervenção processual de outras entidades. $\mathrm{O}$ TEDH entendeu que a aplicação das garantias do artigo $6^{\circ}$ da CEDH a todas as fases do procedimento de investigação das empresas por parte do DTI poderia pôr em causa o objectivo regulatório de protecção do interesse público diante de actividades financeiras e comerciais extremamente complexas.

${ }^{70}$ Veja-se, ainda, os casos Funke v. França, de 25 de Fevereiro de 1993; John Murray v. the United Kingdom, de 8 de Fevereiro de 1996; Saunders v. the United Kingdom, de 17 de Dezembro de 1996,; Serves v. France, de 20 de Outubro de 1997.

${ }^{71}$ Guy Stessens, "The obligation to produce documents versus the privilege against self-incrimination: human rights protection extended too far?”, Human Rights Survey,1997, p. 45/62.

${ }^{72}$ Aplications n ${ }^{\circ}$ 29522/95, n 30056/96, 30574/96, EHRR, 225 (2000). 
No caso Abas v. Netherlands ${ }^{73}$, o TEDH colocou o acento tónico na natureza do procedimento em que os documentos potencialmente incriminatórios são solicitados, considerando que quando se trata apenas de procedimentos normais (v.g. tributários) de verificação da observância das normas legais pertinentes por parte do investigado - ainda que com sanções pela falta de cooperação - sem qualquer intenção de responsabilização ou sanção, não há que aplicar as garantias do artigo $6^{\circ}$ da CEDH. Diferentemente, sempre que se esteja perante um procedimento preponderantemente sancionatório, na sequência da notificação de uma infracção, deve aplicar-se as garantias do artigo $6^{\circ}$ da CEDH.

Desta jurisprudência pode concluir-se pela inteira legitimidade da imposição de um dever de colaboração a entidades reguladas em contextos regulatórios e de supervisão, mesmo garantidos por uma sanção de natureza contraordenacional ou criminal. Assim é, sublinha Marc Berger, desde que os documentos não venham a ser posteriormente utilizados em processo penal ${ }^{74}$. A aplicação das garantias do artigo $6^{\circ}$ da CEDH terá todo o cabimento quando a natureza preponderante do processo passa a ser sancionatória, que não meramente regulatoria.

Igualmente relevante é o caso Shannon $v$. United Kingdom relativo à investigação oficial da conduta de um contabilista, suspeito de fraude fiscal, ao abrigo do Proceeds of Crime Order, de 1996, da Irlanda do Norte. O contabilista foi acusado e condenado por se ter recusado a comparecer pela segunda vez diante do investigador financeiro oficial. O governo britânico defendeu essa solução por considerar que o objectivo estadual de localização dos proveitos da actividade criminosa justifica o exercício de pressão coactiva de forma a obrigar a resposta diante do investigador financeiro oficial.

De acordo com o direito nacional, o investigador financeiro oficial estaria autorizado a transmitir a informação assim obtida às autoridades policiais. No caso, 0 TEDH considerou admissível não só a recusa a responder, mas também a recusa em comparecer a um inquérito potencialmente auto-incriminatório. De acordo com o TEDH, o direito à não auto-incriminação pode ser invocado, não apenas quando as informações incriminatórias obtidas coactivamente são realmente usadas em processos posteriores, mas também quando apenas existe o risco de isso vir a acontecer. Além disso, sustentou o TEDH, o objectivo legítimo de investigar o destino dado aos proveitos da actividade criminosa não é suficiente para afastar a aplicação das garantias do artigo $6^{\circ}$ da CEDH.

Por seu lado, no caso Heaney and Mcguinness $v$. Ireland ${ }^{75}$, o TEDH sustentou que o direito à não auto-incriminação visa assegurar o respeito pela vontade do acusado de permanecer em silêncio, não se aplicando ao requerimento, mediante o uso de poderes compulsórios, do fornecimento de materiais com existência independente da vontade dos peticionantes, como documentos ou amostras de sangue. Note-se, porém, que neste caso não foi aplicada nenhuma sanção pela não entrega dos documentos. Ou seja, o que está em causa é o grau de coação (“degree of compulsion”) aplicado

\footnotetext{
${ }^{73}$ App. No 27943/95, 1997.

${ }^{74}$ Marc Berger, “Europeanizing Self-Incrimination...”, cit., p. 351.

${ }^{75}$ Apps. n. ${ }^{\circ}$ 34720/97, decisão de 21 de Dezembro de 2000.
} 
sobre o requerente para a entrega dos documentos. A aplicação de sanções para coagir alguém a cooperar é que pode atacar o direito à não auto-incriminação, dando lugar a uma violação do art. 6.\%/1 da CEDH.

No caso J.B. v. Switzerland ${ }^{76}$, o que se discutia era a imposição de uma multa ao queixoso pelo facto de não ter fornecido as informações que as autoridades fiscais lhe pediam. No caso, era-lhe pedido que entregasse documentos relativos às companhias nas quais havia investido dinheiro. Não o fez, nem prestou qualquer informação, pelo que foi finalmente sujeito a uma multa.

Tendo em conta as prévias decisões do TEDH, temia-se que este caso fosse decidido como o caso Saunders, em que se explicou que existem situações excluídas da aplicação deste principio, tais como as análises de sangue, urina ou ADN, em relação às quais pode ser imposta a realização do exame mesmo contra a vontade do suspeito. Recorde-se que, como vimos acima, o fornecimento de documentos, porque dotados estes de existência autónoma, foi considerado como não coberto pelo direito à não auto-incriminação, quando fornecido com base num mandato judicial de busca e apreensão.

No entanto, neste caso $J B v$. Switzerland, o TEDH considerou violado o direito à não auto-incriminação, na medida em que os documentos tinham sido obtidos mediante coerção e que os pedidos da Administração fiscal oprimiam o arguido e violavam o seu direito à não auto-incriminação. Ou seja, não se distinguiu entre documentos pré-existentes ou documentos produzidos no momento, tendo-se considerado decisivo o uso de poderes coercivos.

No caso Jalloh v. Germany ${ }^{77}$, o TEDH, julgando em tribunal pleno, estipulou que o critério para aferir se existiria ou não violação do principio da não incriminação se orientava pela análise dos seguintes factores, como a natureza o grau da coerção usada para obter a prova, o peso do interesse público em causa no processo, a existência de salvaguardas adequadas para proteger a pessoa investigada e acusada no processo e utilização do material obtido na investigação. Nos casos O’Halloran and Francis v. the United Kingdom ${ }^{78}$ e Lückhof and Spanner v. Austria ${ }^{79}$, o TEDH reiterou o critério do grau de coerção utilizado na obtenção das provas, a existência de garantias de salvaguarda no processo e o uso dado à informação obtida.

\section{Jurisprudência Comunitária}

Também no âmbito da jurisprudência comunitária o direito em presença tem sido tematizado. No entanto, a orientação seguida no direito comunitário apresenta algumas diferenças relativamente à orientação seguida no quadro do direito europeu dos direitos humanos. Nas linhas que se seguem referiremos apenas alguns leading cases neste domínio, fazendo depois referência ao modo como as diferenças entre estas orientações jurisprudenciais têm sido identificadas e documentadas.

\footnotetext{
${ }^{76}$ N. ${ }^{\circ}$ 31827/96, decisão de 3 de Maio de 2001.

${ }^{77}$ App. [GC], no. 54810/00, decisão de 2006.

${ }^{78}$ App. N. 15809/02 e 25624/02, decisão de 2007.

${ }^{79}$ Application $n^{\text {os }}$ 58452/00 e 61920/00, decisão de 10 de Janeiro de 2008.
} 
No caso Orkem SA v. Comission $^{80}$ o TJCE sustentou que o direito a não ser compelido a prestar testemunho contra si mesmo integra os princípios comuns aos direitos nacionais dos Estados membros, sendo inteiramente aplicável a uma empresa ${ }^{81}$. Isto, apesar de se reconhecer a existência de diferenças significativas entre os Estados, como seja o facto de alguns concederem esse direito em todas as fases do processo e outros apenas nas fases de investigação preliminar e inquérito. Do mesmo modo, nalguns casos o direito inclui as testemunhas, ao passo que noutros se limita a quem tenha sido objecto de acusação formal.

Por seu lado, o Tribunal de $1^{\text {a }}$ Instância, no caso Graphite Electrodes, ${ }^{82}$ afirnou, para além da formulação de questões puramente factuais e pedidos de fornecimento de documentos já existentes, que a exigência, por parte da Comissão, dirigida a um indivíduo, no sentido de que descrevesse o objecto, o conteúdo e as conclusões de uma série de reuniões empresariais, quando era claro que a Comissão suspeitava da verificação de práticas restritivas da concorrência, constituía, pela sua natureza, uma tentativa clara de levar de induzir a confissão da sua participação na violação de normas comunitárias sobre o direito da concorrência.

Refira-se, a este propósito, que as investigações empreendidas pela Comissão no contexto do direito comunitário da concorrência assumem uma natureza claramente sancionatória, na medida em que conduzem à aplicação de pesadas sanções pecuniárias. Por esse facto, as mesmas reconduzem-se, sem margem para dúvidas, ao conceito de “infracções criminais”, tal como o mesmo tem sido concretizado pela jurisprudência do TEDH no âmbito do artigo $6^{\circ}$ da CEDH. No entanto, assiste-se aqui a uma clara divergência de posições jurisprudenciais.

A Comissão tem entendido que os poderes que lhe são concedidos pelo artigo $11^{\circ} / 2 / 5$ do Regulamento $n^{0} 17$ sobre concorrência lhe dão o direito de exigir das empresas todas as informações e documentos respeitantes a factos do seu conhecimento, mesmo que estes possam mais tarde vir a ser usados para estabelecer a existência de práticas anti-competitivas, sem que possam invocar o direito à não auto-incriminação. O Tribunal de Primeira Instância sustentou que o direito ao silêncio só pode ser reconhecido na medida em que a empresa em causa tenha sido obrigada a responder de maneira a admitir a existência de uma infracção cuja prova caiba à Comissão ${ }^{83}$.

A efectividade do artigo $11^{\circ}$ do Regulamento ${ }^{\circ} 17$ implica o poder, da Comissão, de compelir as empresas a fornecer toda a informação necessária relativa aos factos que possam ser do seu conhecimento e de fornecer os documentos com eles relacionados ainda que os mesmos possam vir a ser usados para estabelecer uma conduta anti-competitiva. O poder da Comissão de obter informações, tal como afirmado

\footnotetext{
${ }^{80}$ Orkem v. Commission ECR, 1989, 3283.

${ }^{81}$ Caso Orkem v. Comissão (Case 374/87 [1989] ECR 3283) :“Thus, the Commission may not compel an undertaking to provide it with answers which might involve an admission on its part of the existence of an infringement which it is incumbent on the Commission to prove."

${ }^{82}$ Veja-se, SGL Carbon AG v Commission, a Decisão do Tribunal de Primeira Instância, de 15 de Junho de 2005, e do TJCE, $2^{\mathrm{a}}$ secção, Decisão de 29 de Junho de 2006.

${ }^{83}$ Case T-112/98 Mannesmannröhren-Werke v Commission [2001] ECR II-729, paragraphs 66 and 67.
} 
nos casos Orkem v Commission e Mannesmannröhren-Werke v Commission, é tido pela jurisprudência comunitária como compatível com o artigo 6\%1/2 da CEDH e com a jurisprudência do TEDH, pelo menos até ao caso Funke, sendo que a partir de aí se começam a acentuar as divergências, como é visível nos casos Saunders e J.B.

Ainda assim, a jurisprudência comunitária tem sustentado que o simples facto de se ser obrigado a responder a questões factuais e a fornecer documentos pré-existentes não pode constituir uma violação dos direitos de defesa ou a um julgamento justo e, mais concretamente, do direito à não auto-incriminação. Tanto mais quanto é certo, diz-se, que o destinatário da exigência do fornecimento dos documentos sempre poderia questionar a interpretação que deles é feita pela Comissão, seja numa fase ulterior do procedimento administrativo, seja diante dos tribunais comunitários. Esta posição foi reiterada pelo TJCE no referido caso SLG Carbon, em termos ainda mais restritivos do que os sustentados pelo Tribunal de Primeira Instância.

O TJCE sustentou que o artigo $11^{\%} / 1$ do Regulamento $n^{\circ} 17$ confere à Comissão o poder de obter toda as informações necessárias dos governos dos Estados, das autoridades competentes e das empresas ou associações de empresas. Aos representantes das empresas, a informação deverá ser prestada pelos seus representantes. Uma empresa que esteja a ser investigada não tem o direito de se furtar à investigação, antes devendo cooperar activamente fornecendo à Comissão toda a informação relacionada como o objecto da investigação, mesmo que a mesma possa ser mais tarde utilizada para estabelecer a existência de conduta anti-concorrencial.

A situação já será diferente quando a Comissão procure obter respostas de uma empresa que esteja a ser investigada, mediante as quais a empresa fosse conduzida a admitir uma infracção cuja prova caiba à Comissão. Apesar dos desenvolvimentos jurisprudenciais mais recentes ocorridos no âmbito do TEDH, o TJCE considerou que os mesmos não vão ao ponto de obrigar a uma revisão dos princípios afirmados no caso Orkem v. Commission. Designadamente, não se põe em causa, no entender do TJCE, os poderes da Comissão de exigir documentos pré-existentes, ainda que eles possam ser usados para estabelecer a existência de uma infracção.

Acresce que o TJCE considerou injustificada a decisão do Tribunal de Primeira Instância na parte em que esta deu como demonstrado o facto de que a empresa SLG Carbon tinha sido levada a admitir uma infracção das normas comunitárias de direito da concorrência, considerando que desse modo se enfraquecia o dever de cooperação estabelecido no artigo $11^{\circ}$ do Regulamento $n^{\circ} 17$. De acordo com o TJCE, o dever de cooperação significa que uma empresa não se pode furtar aos pedidos de fornecimento de documentos invocando o direito à não auto-incriminação, tanto mais quanto é certo que a empresa investigada sempre pode questionar, mais tarde, a interpretação dada a esses documentos.

Esta posição do TJCE parece acentuar, ainda mais as divergências jurisprudenciais que, como se disse, a partir do caso Funke se têm vindo a desenhar entre a jurisprudência 
comunitária, tem vindo a apresentar algumas diferenças relativamente à definição do $\mathrm{TEDH}^{84}$. No direito comunitário, o direito à não auto-incriminação tem sido entendido como permitindo que um indivíduo ou uma empresa se recusem a responder a uma questão colocada pela Comissão Europeia, quer se trate de explicar um documento ou de fornecer uma informação, quando isso possa envolver directamente a admissão de uma infracção das normas de concorrência (Orkem, Mannesmannröhren-Werke, SGL Carbon), entendimento que o TJCE acabou por corrigir de forma ainda mais restritiva. Porém, o direito em análise tem sido interpretado como não permitindo que um indivíduo ou uma empresa se recusem a prestar informação factual à Comissão Europeia, seja a explicar um documento ou a fornecer uma informação. Este segundo entendimento apresenta-se contraditório com a jurisprudência do TEDH no caso Saunders.

Acresce que não é seguro que o direito à não auto-incriminação, na sua acepção comunitária, permita que um indivíduo ou uma empresa se recusem a fornecer informação factual à autoridade nacional da concorrência, quer se esteja perante a aplicação do direito interno da concorrência (OFT v. X) quer essa autoridade nacional esteja a agir como “autoridade competente”, de acordo com o Regulamento 17, para efeitos da aplicação do direito comunitário da concorrência. No entanto, também aqui deparamos com o que parece ser uma contradição com a jurisprudência do caso Saunders.

Também não é seguro, além disso, que o direito à não auto-incriminação, na sua acepção comunitária, permita que um indivíduo ou uma empresa se recusem a fornecer documentos ou a submeterem-se a uma busca em resposta ao exercício de poderes compulsórios por parte da autoridade da concorrência, embora isto colida com a jurisprudência dos casos Funke e $J B$. Finalmente, tudo indica que o direito à não auto-incriminação pode permitir que uma pessoa ou uma empresa sob investigação se recuse a fornecer documentos quando isso possa revestir natureza testemunhal e envolver um impacto auto-incriminatório (Saunders, US v. Doe). Neste sentido, o direito à não auto-incriminação não se aplica à informação prestada voluntariamente ou em resposta a pedidos não vinculativos. Do mesmo modo, não se aplica a documentos dirigidos a terceiros.

Vemos, assim, que os contornos precisos do direito à não auto-incriminação ainda não se encontram precisamente definidos. As considerações anteriores demonstram que o direito internacional dos direitos do homem parece conter maiores possibilidades de ampliação do direito à não auto-incriminação, quando comparado com o direito comunitário e mesmo com alguns aspectos da jurisprudência constitucional norte-americana em torno da Quinta Emenda e da respectiva aplicação às pessoas colectivas.

\section{GARANTIAS PROCESSUAIS DAS PESSOAS COLECTIVAS}

\subsection{Titularidade de direitos fundamentais pelas pessoas colectivas}

Do ponto de vista constitucional, a titularidade de direitos fundamentais por parte das pessoas colectivas não oferece qualquer margem para dúvidas. A mesma encontra-se constitucionalmente consagrada, de forma expressa, no quadro do princípio da

${ }^{84}$ Uma boa síntese desta matéria é nos dada pelo University of Oxford Centre for Competition Law and Policy, The Privilege against Self-Incrimination in Competition Investigations, 27 de Janeiro de 2006, estudo em que baseamos estas considerações. 
universalidade dos direitos fundamentais ${ }^{85}$. De resto, muitas das garantias de due process são hoje vistas como concretizações indeclináveis do princípio constitucionalmente estruturante do Estado de direito, pelo que se aplicam sempre que exista um processo sancionatório, independentemente das partes em causa. O facto de se tratar de uma pessoa colectiva não constitui fundamento suficiente para a privação de direitos, liberdades e garantias, sendo expressamente rejeitada a lógica que, nos Estados Unidos, se encontra subjacente à doutrina da "collective entitity". Daí que, à partida, as garantias processuais contraordenacionais, incluindo a conformação que lhes é dada pelo processo penal, sejam aplicáveis às pessoas colectivas, aspecto que tem relevância directa no direito à não auto-incriminação.

Este direito fundamental pretende realizar um equilíbrio constitucionalmente saudável entre os poderes do Estado e os direitos dos cidadãos, equilíbrio esse que também se justifica inteiramente quando se esteja diante de pessoas colectivas, nomeadamente do sector empresarial. Do ponto de vista do direito constitucional e do direito internacional dos direitos humanos nenhuma razão há para excluir a aplicação do direito à não auto-incriminação às pessoas colectivas e aos respectivos representantes. Este direito nasceu como forma de luta contra os modelos inquisitoriais do processo penal, pelo que o mesmo continua a justificar-se nos dias de hoje, mesmo para as empresas.

\subsection{Direito à não auto-incriminação e admissibilidade de provas}

A jurisprudência comparada e europeia nesta matéria tende a considerar que o direito à não auto-incriminação não se aplica a documentos em domínios sujeitos a regulação de interesse público, ou seja, documentos cuja produção e conservação seja exigida pelo Estado para a realização de finalidades administrativas. O direito à não auto-incriminação conhece restrições quando se verifica uma conexão dos documentos com o interesse público. Uma investigação, por parte de uma entidade reguladora, às infracções de uma entidade regulada dentro de um contexto regulatório não cabe, só por esse facto, no âmbito normativo de conceito de "infracção" para efeitos do artigo $6^{\circ}$ da CEDH, muito ficando dependente das circunstâncias do caso.

Nalguns quadrantes entende-se que a admissibilidade destes documentos em processos sancionatórios deve ponderar factores como os interesses em jogo no contexto regulatório em presença, a natureza da relação entre entidade reguladora e entidade regulada, a existência ou não de coerção, o risco de abuso de poder ou de infidedignidade da informação prestada, a gravidade das sanções, etc.

Para além deste tipo de situações, entende-se que não existe nada de inerentemente injusto na utilização de provas que poderiam ter sido descobertas sem recurso a poderes coercivos e cuja qualidade e conteúdo permanecem independentes do recurso a poderes coercivos. Documentos com existência autónoma relativamente ao arguido mais dificilmente estarão protegidos pelo direito à não auto-incriminação. Este ponto tem inteira relevância no contexto da supervisão bancária.

Particularmente relevante é o facto de os documentos terem sido produzidos num contexto regulatório normal, destituído de dimensões adversariais ou de antagonismo

${ }^{85}$ J.J. Gomes Canotilho, Direito Constitucional e Teoria da Constituição, Coimbra, 2003, p. 416 ss. 
procedimental ou processual, em que o objectivo predominante da obtenção de informações era essencialmente regulatório e não o exercício de coacção no sentido de forçar a auto-incriminação. Importa garantir que, ao prestarem informações, os responsáveis pelas entidades reguladas não são sujeitos a quaisquer pressões físicas ou psicológicas. Em todo o caso, como se viu, se os documentos obtidos, mesmo em contexto regulatório, o foram mediante a cominação de sanções no caso da sua recusa, já podem, na verdade, colocar-se problemas sensíveis do ponto de vista do direito à não auto-incriminação.

Como vimos anteriormente, existe uma certa relutância, por parte do TEDH, em aceitar a posterior utilização de documentos obtidos mediante a utilização de mecanismos coercivos, em processos penais instaurados contra indivíduos. O TEDH considerou violador do artigo $6^{\circ}$ da CEDH uma condenação baseada exclusivamente na prova obtida mediante auto-incriminação. De algumas decisões do TEDH parece resultar que se o Estado lança mão de um sistema compulsório de obtenção de informação no contexto regulatório e de investigação baseado na ameaça de sanções penais no caso de recusa a responder, o mesmo não pode, mais tarde, servir-se da informação assim obtida para garantir uma condenação penal. A violação do artigo $6^{\circ}$ da CEDH consumar-se-ia no momento da utilização da informação obtida em processo penal, pondo em causa a justiça do julgamento.

Diferentemente se passam as coisas quando a entidade de supervisão se encontra a investigar infracções contraordenacionais que hajam sido praticadas, ou factos que possam dar lugar a responsabilidade criminal. Nesses casos, começam a ser procedentes algumas das garantias de processo penal, nomeadamente em matéria de revistas, buscas e apreensões, na medida em que se trata de garantias aplicáveis, com as necessárias adaptações, aos processos sancionatórios de mera ordenação social.

Do mesmo modo, o direito à não auto-incriminação tende a adquirir também aí um relevo preponderante, podendo ser invocado, dentro de certos parâmetros, como fundamento de recusa da prestação das informações e documentos pretendidos. Alguma doutrina vai mesmo ao ponto de sustentar que o direito à não auto-incriminação protege a prestação de informações falsas, desde que seja com o intuito de encobrir uma outra infracção anteriormente praticada ${ }^{86}$, posição que nos suscita as mais sérias reservas.

\subsection{Direito processual penal e contra-ordenacional}

Refira-se que a importação das garantias processuais penais para o processo sancionatório de mera ordenação social abrange não apenas a fase judicial do mesmo, em que se contesta judicialmente a sanção cominada pela autoridade administrativa competente, mas também a fase administrativa do processo, em que se discute a verificação dos elementos fácticos e normativos tipificadores da infracção. Na verdade, a aplicação das garantias conhece a plenitude da sua relevância precisamente na fase administrativa anterior à imposição da sanção de mera ordenação social, na medida

${ }^{86}$ Pedro Luis de Amaral Marino, “O Dever de Informar e o Direito ao Silêncio”, Direito Penal Tributário Contemporâneo: Estudos de Especialistas, Cord. Antônio Cláudio Mariz de Oliveira, Dejalma de Campos, São Paulo, 1995, p. 115. 
em que a fase judicial do processo é facultativa, supondo sempre a contestação de uma decisão prévia aplicada no termo da fase administrativa do processo. Daí que o processo de mera ordenação social deva ser visto na sua unidade, administrativa e judicial, aplicando-se à unidade de processo a unidade de garantias ${ }^{87}$.

Esta clara aproximação do direito de mera ordenação social relativamente ao direito penal, quer no plano substantivo, quer no plano processual, é uma realidade também noutros ordenamentos jurídicos, tendo sido expressamente caucionada pelo próprio TEDH. Este tribunal tem considerado que as contra-ordenações, a despeito do programa de descriminalização que lhes está subjacente, não afastam necessariamente a aplicação das garantias do artigo $6^{\circ}$ da $\mathrm{CEDH}$, apesar de estas terem primeiramente em vista o processo penal, particularmente, embora não exclusivamente, quando esteja em causa a sanção de condutas socialmente censuráveis, ainda que sem um desvalor penal, mediante a aplicação de sanções severas, ainda que não privativas da liberdade ${ }^{88}$.

De acordo com este entendimento, o direito de mera ordenação social é aplicado num contexto processual sancionatório, sendo-lhe estendidas as garantias do artigo $6^{\circ}$ da CEDH. Assim, partindo de uma interpretação ampla da noção de infracção, não circunscrita às infracções penais, o TEDH tem entendido que as garantias de processo criminal são válidas mesmo no contexto do ilícito de mera ordenação social, estando nelas incluído o direito à não auto-incriminação.

4.4. Direito à não auto-incriminação processos contraordenacionais e penais

$\mathrm{O}$ alargamento da imputabilidade das infracções contraordenacionais às pessoas colectivas milita, naturalmente, a favor do correspectivo alargamento das garantias processuais. Por outras palavras, quanto maiores forem as possibilidades de imputação de uma conduta à pessoa colectiva, especialmente num contexto vicarial ou substitutivo, tanto maiores devem ser as garantias processuais reconhecidas à pessoa colectiva.

Não oferece quaisquer dúvidas a possibilidade de invocação do direito à não auto-incriminação no contexto de processos sancionatórios de natureza administrativa, como é o caso do direito de mera ordenação social. E isto, como anteriormente se disse, quer os arguidos sejam pessoas colectivas, quer sejam pessoas singulares. $\mathrm{Na}$ verdade, os mesmos factos podem responsabilizar tanto umas como outras, pelo que a aplicação do direito à não auto-incriminação tem todo o cabimento em ambos os casos. Se uma pessoa colectiva não for protegida quando um dos seus representantes é chamado a revelar informações, a mesma nunca será protegida e provas contra ela apresentadas pelos seus directores ou representantes seriam sempre admissíveis.

O direito à não auto-incriminação das pessoas colectivas não pode ser subvertido ou neutralizado através da obrigação dos respectivos directores ou representantes de apresentarem provas contra elas, sob pena de o mesmo perder qualquer sentido útil. No entanto, mesmo que se não quisesse aplicar o direito à não auto-incriminação às pessoas colectivas, posição que nos parece constitucionalmente insustentável, sempre

${ }^{87}$ Neste sentido, Frederico da Costa Pinto, “Tendências da Jurisprudência sobre Contraordenações no Âmbito do Mercado de Valores Mobiliário”, Cadernos do Mercado de Valores Mobiliários, 8, Agosto 2000, p. 22-23.

${ }^{88}$ Veja-se, o caso Öztürk v. Federal Republic of Germany, App No. 8544/79, ECHR, (1984). 
se teria que aceitar que os directores da empresa são protegidos pelo direito à não auto-incriminação, mesmo que isso não se aplique à pessoa colectiva propriamente dita.

Quando se trata apenas de procedimentos normais (v.g. tributários) de verificação da observância das normas legais pertinentes por parte do investigado - ainda que com sanções pela falta de cooperação - sem qualquer intenção de responsabilização ou sanção, não há que aplicar as garantias do artigo $6^{\circ}$ da CEDH. Diferentemente, tudo indica que a alteração do objectivo predominante, de regulatório para sancionatório, possa ter algumas consequências do ponto de vista da auto-incriminação. Especialmente assim será se existir, no horizonte, a possibilidade de responsabilização criminal de pessoas singulares que prestem ou tenham prestado serviços na instituição sujeita a supervisão.

Assim é, nesses casos, porque a entidade supervisionada e os particulares com ela directamente relacionados estabelecem, nesse caso, uma relação adversarial de natureza procedimental (aplicação de sanções contraordenacionais) e processual (aplicação de sanções penais). Ou seja, sempre que se esteja perante um procedimento preponderantemente sancionatório, na sequência de uma notificação de uma infracção, deve aplicar-se as garantias do artigo $6^{\circ}$ da CEDH.

Essa relação adversarial surge quando se torna claro que a entidade supervisora tem elementos que lhe permitam considerar que foi cometida uma infracção criminal. Nesse contexto, devem considerar-se admissíveis todos os documentos produzidos ainda num contexto regulatório, desprovido de qualquer pressão coerciva. O direito à não auto-incriminação pretende, acima de tudo, prevenir a obtenção de prova testemunhal mediante coerção.

O fornecimento de documentos só se encontrará protegido pelo direito à não auto-incriminação quando não estiver coberto por um mandato de busca e apreensão e assumir um relevo testemunhal preponderante. $\mathrm{O}$ direito à não auto-incriminação pode ser invocado como defesa para a exigência administrativa de documentos cuja existência é incerta. O direito à não auto-incriminação pretende reagir contra ordens administrativas de conteúdo muito genérico em que se solicite, do visado, a produção de documentos cuja existência não é clara. Excluída pelo direito à não auto-incriminação está a prova testemunhal que o arguido foi obrigado a criar e não a prova com existência independente que o arguido foi compelido a ajudar a localizar, a identificar ou a explicar.

Relativamente às afirmações feitas no contexto regulatório, as mesmas devem ser avaliadas pelo risco de falsas confissões e condenações indevidas. Neste contexto, o facto de alguém saber que as informações prestadas podem ser usadas contra si em processo penal cria um forte incentivo no sentido de prestar falsas informações. Num contexto regulatório, em que os interesses em presença exijam a máxima honestidade, pode ser útil conceder imunidade em processo sancionatório. Em princípio caberá ao legislador tomar essa decisão, na medida em que ela implica que a obtenção de provas para processo criminal deve ser conseguida por outras vias. Em todo o caso, se isso não estiver expressamente previsto na lei, deve entender-se que os documentos serão sempre admissíveis, mesmo em procedimentos sancionatórios, se foram produzidos em contextos não coercivos, não intimidatórios e não manipulativos. 


\subsection{Situações de violação do direito à não auto-incriminação}

A jurisprudência comparada que tem considerado que o direito à não auto-incriminação abrange, em princípio, a comunicação testemunhal incriminatória e não a prova documental. No entanto, o direito à não auto-incriminação terá aplicação se se tratar de documentação contendo aspectos testemunhais e efeito incriminatório. De acordo com esta orientação jurisprudencial, sempre que o fornecimento de documentos, por ordem da Administração, tiver um relevo testemunhal e um impacto auto-incriminatório, o mesmo é precludido pelo direito à não auto-incriminação. O relevo testemunhal dos documentos afere-se pelo respectivo conteúdo informativo, isto é, pela quantidade de informação factual nova que transmitem à Administração.

Reconhece-se, assim, que, ao menos nalguns casos, o fornecimento de documentos pode ter valor testemunhal, declarativo e comunicativo, bem como confirmar a existência, posse e autenticidade do documento a fornecer. Por esta forma pretende-se reagir contra ordens administrativas de conteúdo muito genérico em que se solicite, do visado, a produção de documentos cuja existência não seja clara. Desse modo, limitou-se o poder da Administração de forçar os particulares a confessar a existência de documentos de existência incerta. Refira-se que em muitos casos será possível obter os documentos através de alguém que não corra o risco de incriminação ${ }^{89}$.

Ainda assim, duas ordens de considerações têm sido usadas para limitar o direito à não auto-incriminação. A primeira, distingue entre documentos públicos e privados, procurando circunscrever a protecção do direito à não auto-incrimimação apenas ou principalmente aos documentos privados, no quadro da protecção contra buscas e apreensões irrazoáveis e da protecção do direito à reserva da vida privada. A segunda, tem colocado o acento tónico na questão de saber se o respectivo conteúdo foi fornecido de forma voluntária ou sob coacção. Isto de forma a reconduzir ao âmbito de protecção do direito à não auto-incriminação apenas o testemunho prestado sob coacção.

Nalguns quadrantes, o direito à não auto-incriminação pode ser invocado, prima facie, em resposta a questões ou a pedidos de prestação de documentos, sejam eles pré-existentes ou criados no momento do pedido, desde que tenham sido utilizados meios compulsórios para o efeito. O fornecimento de documentos só se encontrará protegido pelo direito à não auto-incriminação quando não estiver coberto por um mandato de busca e apreensão e assumir um relevo testemunhal preponderante.

O direito à não auto-incriminação já se aplicará no caso de documentos produzidos no momento em que é solicitado o seu fornecimento (v.g. confissões filmadas ou escritas), desde que a sua produção esteja dependente de um pedido específico formulado pelo investigador. Noutras situações, em que o risco de confissões forçadas é menor, existe uma maior relutância à aplicação da protecção contra a auto-incriminação (v.g. documentos elaborados em contextos regulatórios; documentos elaborados para ocultar provas), ao menos quando não houver recurso a meios compulsórios. Isto, sem esquecer a existência de posições mais restritivas do direito à auto-incriminação no caso das pessoas colectivas, designadamente no âmbito do direito comunitário e do direito norte-americano.

${ }^{89}$ Foster, The Right Against Self-Incrimination by Producing Documents..., cit., 1640 ss. 
A exigência, por parte da Administração, do fornecimento de documentos cuja existência seja incerta, configura mais facilmente uma violação do direito à não autoincriminação, mesmo que a Administração não pudesse ou não quisesse obtê-los de outro modo. Isto, ainda que a Administração disponha de elementos que possam sugerir a existência dos documentos solicitados e mesmo que os mesmos não tenham sido utilizados num processo penal. Neste sentido milita não apenas o artigo $6^{\circ}$ da $\mathrm{CEDH}$, mas também o artigo $8^{\circ}$ do mesmo instrumento, que protege o direito à privacidade. Esta orientação jurisprudencial tende a não abranger os elementos recolhidos, mesmo de forma compulsória, que tenham uma existência autónoma relativamente ao arguido, como sejam documentos, amostras de sangue e urina, ou outro material biológico para efeitos de testes de ADN. No entanto, se existir coerção, a distinção entre documentos pré-existentes e documentos produzidos no momento pode passar para segundo plano, a serem aceites as teses sustentadas pelo TEDH.

No direito comunitário, o direito à não auto-incriminação foi entendido, a certa altura, como permitindo que um indivíduo ou uma empresa se recusem a responder a uma questão colocada pela Comissão Europeia, quer se trate de explicar um documento ou de fornecer uma informação, quando isso possa envolver directamente a admissão de uma infracção das normas de concorrência (Orkem, Mannesmannröhren-Werke, SGL Carbon).

No entanto, como se viu, este entendimento acabou ser revisto em baixa pelo TJCE, que privilegiou o dever de colaboração nas investigações da Comissão em detrimento da proteç̧ão contra a auto-incriminação. No âmbito comunitário dá-se como assente que o direito em análise não permite que um indivíduo ou uma empresa se recusem a prestar informação factual à Comissão Europeia, quer se trate de explicar um documento ou de fornecer uma informação, ainda que isso possa envolver a admissão de uma infraç̧ão ou ser utilizado posteriormente para estabelecer a existência de uma.

As jurisprudências comparada e europeia nesta matéria tendem a considerar que o direito à não auto-incriminação vê o seu campo de aplicação substancialmente limitado em domínios sujeitos a regulação de interesse público, ou seja, relativamente a documentos cuja produção e conservação seja exigida pelo Estado para a realização de finalidades administrativas de natureza regulatória. O direito à não auto-incriminação conhece restrições quando se verifica uma conexão dos documentos com o interesse público. Uma investigação, por parte de uma entidade reguladora, às infracções de uma entidade regulada dentro de um contexto regulatório não cabe necessariamente no âmbito normativo de infraç̧ão para efeitos do artigo $6^{\circ}$ da CEDH.

Como vimos anteriormente, as coisas podem alterar-se substancialmente, ao menos numa perspectiva de direito internacional dos direitos humanos, se o documento tem um relevo preponderantemente testemunhal e privado, se foi obtido mediante coerção ou se se está num contexto preponderantemente sancionatório. Tende a considerar-se que não existe nada de inerentemente injusto na utilização de provas que poderiam ter sido descobertas sem recurso a poderes coercivos e cuja qualidade e conteúdo permanecem independentes do recurso a poderes coercivos. Documentos com existência autónoma relativamente ao arguido mais dificilmente estarão protegidos pelo direito à não auto-incriminação. Em todo o caso, se existe alguma possibilidade de ampliação do direito à não auto-incriminação, ela parece ser 
mais realista à luz da orientação mais generosa seguida pelo TEDH do que da posição mais restritiva adoptada pelo TJCE.

4.6. Utilização dos elementos obtidos em futuros processos contraordenacionais e penais

Afigura-se inteiramente legítima a imposição de um dever de colaboração às entidades reguladas em contextos regulatórios e de supervisão, mesmo garantidos por uma sanção de natureza contraordenacional ou criminal, desde que os documentos assim obtidos não venham a ser posteriormente utilizados em processo penal. Neste sentido se tem orientado o TEDH, diferentemente do que sucede com o TJCE.

A aplicação das garantias do artigo $6^{\circ}$ da $\mathrm{CEDH}$ terá todo o cabimento quando a natureza do processo passa a ser preponderantemente sancionatória, que não meramente regulatoria. Se o Estado lançar mão de um sistema compulsório de obtenção de informação no contexto regulatório, baseado na ameaça de sanções penais no caso de recusa a responder, o mesmo não pode, mais tarde, servir-se da informação assim obtida para garantir uma condenação penal. A violação do artigo $6^{\circ}$ da CEDH consumar-se-ia no momento da utilização da informação obtida em processo penal, pondo em causa a justiça do julgamento. Assim, a prevalecer este entendimento mais aberto, a utilização, como única prova, em processos de contraordenação ou penais, de documentos anteriormente obtidos em contexto regulatório, mas sob a ameaça da imposição de sanções, pode levantar problemas do ponto de vista do direito à não auto-incriminação.

Este entendimento tem a seu favor do facto de, sem comprometer o interesse público na investigação das infracções, conferir uma protecção mais elevada aos direitos de defesa das pessoas colectivas envolvidas em processos sancionatórios, bem como aos respectivos representantes. Essa protecção justifica-se dados os riscos que a confluência de factores como uma maior pressão regulatória, a posição de vulnerabilidade no mercado e a exposição à opinião pública pode representar para a actividade e a viabilidade económica das empresas. Esses riscos podem influenciar negativamente a sua capacidade para apresentar uma defesa ponderada, circunstanciada e fidedigna em processos de infracção de natureza contra-ordenacional, podendo levá-las a confessar infracções denunciadas e não cometidas, pagando a respectiva sanção pecuniária, do que a suportar os custos, no mercado, de uma prolongada exposição mediática em virtude da sujeição a um processo de infracções.

Importa, portanto, não criar situações em que as empresas sejam obrigadas a abrir mão dos seus direitos de defesa, o dos direitos dos seus representantes, apenas porque não conseguem suportar os danos, para o seu bom nome e reputação, resultantes da sua conotação pública com uma determinada infracção, danos esses que podem ser devastadores mesmo que não tenham efectivamente cometido a alegada infracção ${ }^{90}$.

A desconsideração do direito à não auto-incriminação por parte das pessoas colectivas poderia, no caso das empresas, aumentar significativamente os custos económicos do exercício das garantias de defesa mais elementares, com assento no

${ }^{90}$ Este aspecto é salientado por, Earl J. Silbert and Demme Doufekias Joannou, "Under Pressure to Catch the Crooks: The Impact of Corporate Privilege Waivers on the Adversarial System”, 43 American Criminal Law Review, 2006, pp. 1225 ss. 
direito constitucional e no direito internacional ${ }^{91}$. Existem, assim, razões substantivas ponderosas que justificam uma preocupação séria com as implicações do direito à não auto-incriminação das pessoas colectivas e dos seus representantes, na linha da jurisprudência seguida pelo TEDH.

\subsection{Utilização dos elementos obtidos contra pessoas singulares}

Os titulares do direito à não auto-incriminação são os indivíduos e as pessoas colectivas. A invocação do direito pode ser feita pelo próprio titular ou pelo seu representante legal e é independente do estatuto processual da pessoa, podendo a ele recorrer quem seja testemunha, suspeito, indiciado ou arguido num processo sancionatório. $\mathrm{O}$ âmbito normativo do direito abrange as pessoas físicas que representem a pessoa colectiva e que corram o risco de vir a ser incriminadas com base em informações prestadas em representação da pessoa colectiva.

Não só é admissível a notificação destas pessoas para comparecerem num determinado local, a uma determinada hora para prestar declarações sobre um assunto de interesse governamental) a estas pessoas, como também o é que determinados documentos sejam utilizados contra elas em tribunal. No entanto, as mesmas podem valer-se do direito à não auto-incriminação, sempre que a sua intervenção processual resulte num risco sério de fornecimento de provas de grande relevo testemunhal e potencial auto-incriminatório mediante o exercício de poderes coercitivos.

Os limites à produção de prova impostos pelo direito à não auto-incriminação revestem-se da maior importância quando, a par da responsabilidade contraordenacional da pessoa colectiva em causa, haja lugar à responsabilidade pessoal dos titulares dos órgãos de administração da pessoa colectiva, bem como dos responsáveis pela direcção ou fiscalização de áreas de actividade em que tenha sido praticada a contraordenação, desde que, conhecendo ou devendo ter conhecido a prática da infracção, não tenham adoptados as medidas adequadas para lhes por termo.

A protecção do direito à não auto-incriminação das pessoas colectivas e das pessoas singulares a elas ligadas é uma realidade praticamente incindível. $\mathrm{O}$ direito à não auto-incriminação das pessoas colectivas é indissociável do mesmo direito das pessoas singulares que de alguma forma a representam. Se uma pessoa colectiva não for protegida quando um dos seus representantes é chamado a revelar informações, a mesma nunca será protegida e as provas contra ela apresentadas pelos seus directores serão sempre admissíveis, resultado claramente inaceitável à luz dos princípios jurídicos relevantes. O direito à não auto-incriminação das pessoas colectivas não pode ser subvertido através da obrigação dos seus directores, ou representes, de apresentarem provas contra elas, sob pena de o mesmo perder qualquer sentido útil. Na verdade, a garantia do direito à não auto-incriminação às pessoas singulares representativas da pessoa colectiva não visa apenas protegê-las directamente, antes constitui também um meio de garantir a protecção contra a auto-incriminação às próprias pessoas colectivas.

\section{CONCLUSÃO}

O direito à não auto-incriminação integra hoje as dimensões essenciais do due process of law, sendo uma realidade incontornável em todos os processos sancionatórios,

${ }^{91}$ Ellard, Making the Silent Speak and the Informed Wary..., cit., 985 ss. 
incluindo o direito de mera ordenação social. Dele são titulares não apenas os indivíduos, como também as pessoas colectivas. O mesmo pode ser invocado diante de um tribunal comum num processo penal, bem como num processo civil ou administrativo, sempre que exista um risco razoável de um processo penal subsequente. Por maioria de razão aplica-se também a processos disciplinares.

O direito à não auto-incriminação pretende tutelar os direitos legítimos dos arguidos, estando ao serviço do direito a um julgamento justo e da presunção da inocência. No entanto, ele não é um direito absoluto, não podendo ser interpretativamente transformado num obstáculo à realização da justiça. A jurisprudência constitucional norte-americana e a jurisprudência do TJCE, têm procurado garantir algumas dimensões essenciais do direito à não auto-incriminação das pessoas colectivas, sem deixar de preservar a capacidade das entidades reguladoras e de supervisão para controlarem a observância das disposições legais pertinentes por parte das grandes empresas.

A jurisprudência internacional de direitos humanos do TEDH tem colocado o acento tónico na natureza do procedimento em que os documentos potencialmente incriminatórios são solicitados, considerando que, quando se trata apenas de procedimentos normais de verificação da observância das normas legais pertinentes por parte do investigado - ainda que com sanções pela falta de cooperação - sem qualquer intenção de responsabilização ou sanção, não há que aplicar as garantias do artigo $6^{\circ}$ da CEDH. Diferentemente, sempre que se esteja perante um procedimento preponderantemente sancionatório, na sequência da notificação de uma infracção, deve aplicar-se as garantias do artigo $6^{\circ}$ da CEDH. Tem sido igualmente entendido que as contraordenações, a despeito do programa de descriminalização que lhes está subjacente, não afastam necessariamente a aplicação das garantias do artigo $6^{\circ}$ da CEDH.

No entanto, o justo equilíbrio em torno deste princípio pode não ter sido ainda alcançado, havendo lugar ainda para muita controvérsia. É natural que à medida que se agudiza a desconfiança dos Estados e da opinião pública relativamente ao funcionamento do mercado e à racionalidade e credibilidade económica dos seus agentes, na sequência da crise financeira internacional, o direito à não auto-incriminação venha a conhecer pressões acrescidas. Uns irão procurar reduzi-lo ao estritamente necessário, acentuando a necessidade de um controlo estadual efectivo da actividade das grandes empresas. Esta linha da orientação baseia-se no objectivo, inteiramente legítimo, de impedir que o direito em presença venha a constituir um obstáculo intransponível à garantia da legalidade e à realização da justiça.

Outros, procurarão certamente sublinhar que este clima de desconfiança favorece a procura de escalpes e de bodes expiatórios, pelo que o direito à não auto-incriminação se afigura, talvez, mais importante do que nunca. Esta orientação baseia-se na noção, inteiramente correcta, de que mesmo em momentos de crise, e especialmente neles, o conteúdo essencial do direito fundamental a um julgamento justo não pode ser posto em causa. Em última análise, tudo indica que também aqui se deve procurar uma correcta ponderação e harmonização dos princípios em conflito, dentro de uma óptica de concordância prática e máxima efectividade. 